\title{
Last Glacial Maximum records in permafrost of the East Siberian Arctic
}

\author{
Sebastian Wetterich ${ }^{\mathrm{a}, *}$, Natalia Rudaya ${ }^{\mathrm{b}}$, Vladimir Tumskoy ${ }^{\mathrm{c}}$, Andrei A. Andreev ${ }^{\mathrm{d}}$, Thomas Opel ${ }^{\mathrm{e}}$, \\ Lutz Schirrmeister $^{\mathrm{a}}$, Hanno Meyer ${ }^{\mathrm{a}}$
}

\footnotetext{
a Alfred Wegener Institute for Polar and Marine Research, Department of Periglacial Research, Telegrafenberg A43, 14473 Potsdam, Germany

${ }^{\mathrm{b}}$ Institute of Archaeology and Ethnography SB RAS, Ak. Lavrentieva 17, 630090 Novosibirsk, Russia

${ }^{\mathrm{c}}$ Moscow State University, Faculty of Geology, Department of Geocryology, Vorob'evy Gory, 119899 Moscow, Russia

${ }^{\mathrm{d}}$ University of Cologne, Institute of Geology and Mineralogy, Zülpicher Str. 49a, 50674 Cologne, Germany

${ }^{\mathrm{e}}$ Humboldt Universität zu Berlin, Institute of Geography, Department of Climatology, Unter den Linden 6, 10099 Berlin, Germany
}

\section{A R T I C L E I N F O}

\section{Article history:}

Received 12 April 2011

Received in revised form

18 July 2011

Accepted 21 July 2011

Available online $\mathrm{xxx}$

\section{Keywords:}

Ice Complex

Ground ice

Stable water isotopes

Pollen

Yedoma

New Siberian Archipelago

Laptev Sea

Late Pleistocene

\begin{abstract}
A B S T R A C T
Palaeontological proxy data and cryolithological information from Siberian Arctic permafrost preserves records of late Quaternary climate and environmental conditions in West Beringia and their variability which results from interglacial-glacial and interstadial-stadial dynamics. To date, the Last Glacial Maximum (LGM) period has been rather poorly represented in East Siberian permafrost records. Here, we present pollen, sediment, and ground-ice stable water isotope data obtained from coastal exposures on Bol'shoy Lyakhovsky Island (New Siberian Archipelago, Arctic Ocean) that mirror the coldest conditions during the Sartan period between about 26 and $22 \mathrm{ka}$ BP, using pollen and sediment data for summer conditions and stable water isotope data for winter conditions. The pollen record revealed a cold tundra-steppe vegetation with characteristic predominance of grass pollen over sedge pollen while the stable isotope ice-wedges data indicate extremely cold winter temperatures with mean values of $\delta^{18} \mathrm{O}$ of about $-37 \%$ o $\delta$ of about $-290 \%$. Combined with available regional LGM permafrost records that extend from the Taymyr Peninsula in the west to the Yana River lowland in the east, the new data set from Bol'shoy Lyakhovsky Island indicate that the regional appearance of LGM conditions depended on atmospheric circulation patterns that were influenced by the extent of the Northern Hemisphere glaciation.
\end{abstract}

(c) 2011 Elsevier Ltd. All rights reserved.

\section{Introduction}

Permafrost is increasingly employed as an archive that preserves records of Beringian environmental conditions (e.g. Sher et al., 2005; Froese et al., 2008; Andreev et al., in press; Berman et al., in press; Kanevskiy et al., in press). During the late Pliocene and Pleistocene vast areas of the Arctic lowlands between the Eurasian Ice Sheet to the west and the Laurentide and Cordilleran ice sheets to the east remained non-glaciated. Mountain glaciations of different timing and extent are known from East Siberia (Stauch and Gualtieri, 2008), but never reached the Arctic lowlands. Permafrost formation took place since the late Pliocene (first permafrost evidence in NE Siberia from 2.4 to 1.9 Ma ago; Arkhangelov et al., 1996), and persisted over the entire Pleistocene,

\footnotetext{
* Corresponding author. Tel.: +49 331288 2207; fax: +49 3312882188 .

E-mail addresses: sebastian.wetterich@awi.de (S. Wetterich), nrudaya@gmail.com (N. Rudaya), vtumskoy@rambler.ru (V. Tumskoy), aandreev@uni-koeln.de (A.A. Andreev), thomas.opel@geo.hu-berlin.de (T. Opel), lutz.schirrmeister@awi.de (L. Schirrmeister), hanno.meyer@awi.de (H. Meyer).
}

although permafrost strongly degraded during warm periods (e.g. during the last Interglacial ca 130 to 115 ka ago; e.g. Kaplina, 2011; Kienast et al., in press). During glacial periods fine-grained permafrost deposits accumulated under continental, cold climate conditions in the polygon tundra environments of the Arctic lowlands. Characteristic for such deposits are high ice contents in the frozen ground and the occurrence of synsedimentary (syngenetic) ice wedges. This late Pleistocene permafrost type is named 'Ice Complex' (in Russian: ledovyi kompleks, Solov'ev, 1959) or 'Yedoma' (Sher, 1997) in the western part of Beringia, i.e. in East Siberia. Vegetation and faunal reconstructions from this exceptional palaeoenvironmental archive indicate that the sediments largely aggraded in a cryoxeric environment with tundra-steppe vegetation characterised by grass- and herb-rich communities which supported the grazing mammal population of the so-called 'Mammoth fauna' (e.g. Andreev et al., in press).

One of the most promising study areas for collecting information that can be used to highlight the environmental history of West Beringia is Bol'shoy Lyakhovsky Island $\left(73^{\circ} 10^{\prime}\right.$ to $73^{\circ} 55^{\prime} \mathrm{N}$, $139^{\circ} 45^{\prime}$ to $143^{\circ} 35^{\prime} \mathrm{E}$ ). It is the southernmost island of the New 
Siberian Archipelago located between the Laptev and the East Siberian seas (Fig. 1). The southern coast of Bol'shoy Lyakhovsky Island exposes permafrost outcrops that feature frozen sediments, ground ice, and fossil remains dating from the mid-Pleistocene (Andreev et al., 2004). An overview of common stratigraphic terms that are used throughout this paper is given in Table 1, although a valid definition of stadial and interstadial periods of the last glacial period in East Siberia has so far not been agreed upon (Sher et al., 1987; Tumskoy and Basilyan, 2009). The existence of an ongoing discussion about period definitions is obvious from strata names that vary on regional and local scales and a large deficit in or lack of reliable geochronology (for overview see Pitul'ko et al., 2007).

The Laptev Sea region, which is part of West Beringia, has not been glaciated since at least the Tazov Glacial; thus, its local permafrost deposits have been preserved for more than 200 ka (Schirrmeister et al., 2002a). Intense work on coastal outcrops of the island began long ago, starting with the first descriptions in the 19th century (Bunge, 1887; von Toll, 1897) and followed by mostly geocryological research in the 20th century (e.g. Romanovskii, 1958; Nagaoka et al., 1995; Kunitsky, 1998). A comprehensive overview of palaeoenvironmental research on Bol'shoy Lyakhovsky Island extending from the Tazov Glacial to the Holocene was recently presented by Andreev et al. $(2004,2009)$ based on Russian-German joint fieldwork in 1999. These studies used a combination of cryolithological, sedimentological, geochronological, and palaeontological methods, first
Table 1

Compilation of regional stratigraphical units for the period of Ice Complex formation (adapted from Velichko et al., 2005; Pitul'ko and Pavlova, 2010; Andreev et al., in press). Note different definitions of the Kargin interstadial to Sartan stadial transition: *according to Andreev et al. (in press), and **according to Pitul'ko and Pavlova (2010).

\begin{tabular}{|c|c|c|c|c|}
\hline Ages [ka BP] & Period & & $\begin{array}{l}\text { Northeast } \\
\text { Siberia }\end{array}$ & West Europe \\
\hline $\begin{array}{l}\text { ca } 10.5-0 \\
\text { ca } 13-10.5\end{array}$ & $\begin{array}{l}\text { Interglacial } \\
\text { Lateglacial } \\
\text { transition }\end{array}$ & & Holocene & Holocene \\
\hline ca $30 * / 24 * *-13$ & Glacial & Stadial & Sartan & Late Weichselian \\
\hline ca $50-30^{*} / 24^{* *}$ & & Interstadial & Kargin & Middle Weichselian \\
\hline ca $115-50$ & & Stadial & Zyryan & Early Weichselian \\
\hline ca $130-115$ & Interglacial & & Kazantsevo & Eemian \\
\hline ca $200-130$ & Glacial & & Tazov & Late Saalian \\
\hline
\end{tabular}

to describe and date the different permafrost units, and second to apply multiple palaeoenvironmental approaches using pollen, plant macrofossils, diatoms, rhizopods, and mammal bones. Descriptive and numerical reconstructions of past climate and environmental conditions were obtained for e.g. the Lateglacial to Holocene transition (Andreev et al., in press). Additional studies with a focus on Kazantsevo Interglacial plant macrofossils (Kienast et al., 2008), chironomids from the same period (Ilyashuk et al., 2006), and ostracods from Interglacial, Lateglacial and Holocene deposits of Bol'shoy Lyakhovsky Island (Wetterich et al., 2009) complete the

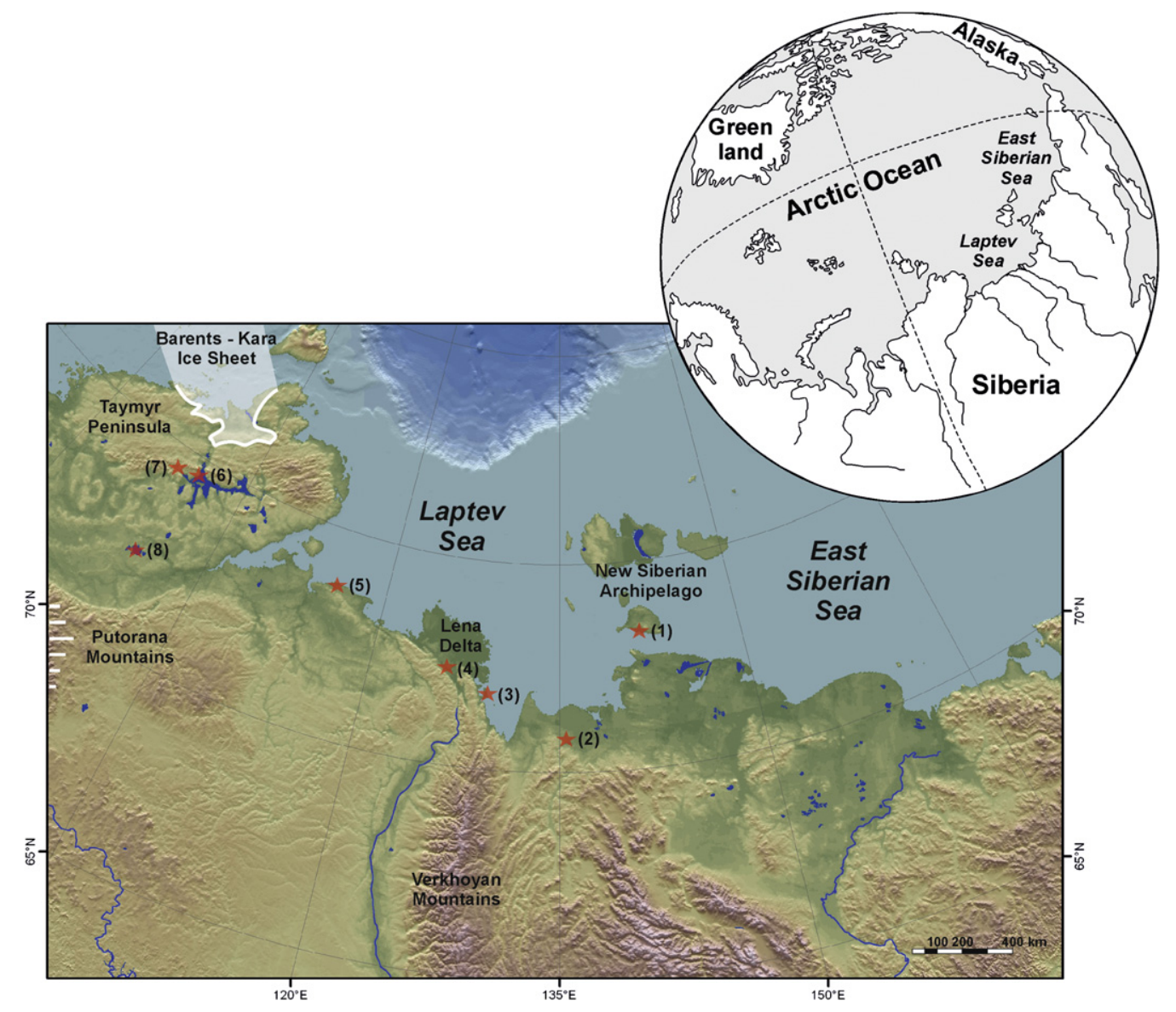

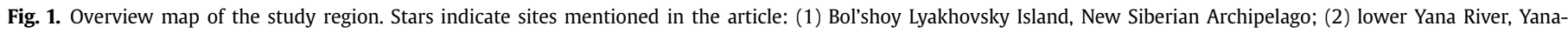

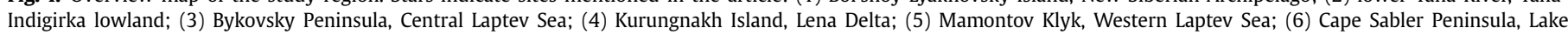

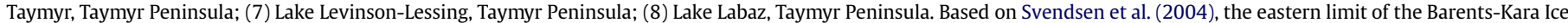

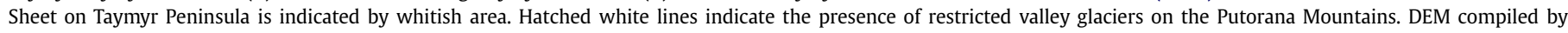
G. Grosse (University of Alaska, Fairbanks, AK). 
palaeoenvironmental data. Along with the sedimentological and palaeontological records of frozen deposits, ground-ice data can be used to deduce palaeoenvironmental information because its formation, manifestation, and preservation largely depend on climatic controls.

Striking forms of ground ice in the late Pleistocene permafrost are ice wedges. Ice wedges are indicative of stable, cold climate conditions, because they form as winter thermal-contraction cracks in the ground which are periodically filled, primarily by snowmelt. The water freezes at negative ground temperatures, forming vertical ice veins (Lachenbruch, 1962) and thus preserving a winter climate signal. With ongoing sedimentation and iterative frost cracking and ice vein formation, ice wedges grow syngenetically in both horizontal and vertical directions. Geochemical studies of stable oxygen $\left(\delta^{18} \mathrm{O}\right)$ and hydrogen $(\delta \mathrm{D})$ isotopes in ice wedges enable reconstructions of past winter temperatures (e.g. Vasil'chuk and Vasil'chuk, 1995) and atmospheric moisture sources (e.g. Meyer et al., 2010). Several ice wedges from six different stratigraphic units on Bol'shoy Lyakhovsky Island have been investigated by Meyer et al. (2002a); these investigations highlighted winter climate conditions from the Tazov Glacial to the Holocene. Intrasedimental ice (texture ice lenses and layers) forms by the freezing of soil moisture in the uppermost seasonally-thawed layer above the permafrost table. Due to multiple freezing and thawing before the texture ice enters a perennially frozen state and to mixed sources of summer and winter precipitation (Vaikmäe, 1989), the stable water isotope composition of texture ice is much heavier than that of ice wedges. The soil moisture preserved as texture ice, however, has been used as a sensitive proxy for climate conditions; this is valid when the data are considered with caution (Mackay, 1983; Schwamborn et al., 2006, 2008).

Despite the great effort that has been expended to highlight the regional history using Bol'shoy Lyakhovsky permafrost records, which are representative of the late Quaternary environmental and landscape dynamics on West Beringia, not all periods have yet been unambiguously recognised, sampled, and dated. West Beringian permafrost records from the last cold stage of the late Pleistocene, i.e. the Sartan stadial that includes the Last Glacial Maximum (LGM), the coldest and driest period of the last glacial period, are rare. In this context the interaction between glaciated and not glaciated Arctic areas are of special interest (Hubberten et al., 2004; Svendsen et al., 2004). On a global scale Clark et al. (2009) recently stated that nearly all ice sheets reached their LGM positions from $26.5 \mathrm{ka}$ to 20 to $19 \mathrm{ka}$, in response to orbital and internal climate forcings.

In this study, the first radiocarbon, cryolithological, stable water isotope, geochemical, and palynological data from Sartan permafrost deposits from Bol'shoy Lyakhovsky Island are presented in the context of concurrent regional data sets (Fig. 1). This study, therefore, fills an existing gap in regional chronology and stratigraphy, and contributes to the late Quaternary palaeoenvironmental database of the Northeast Siberian Arctic.

\section{Study area}

The New Siberian Archipelago is located east of the tectonicallyactive Gakkel-Ust Lena Rift zone that divides the North American and the Eurasian lithosphere plates (e.g. Drachev et al., 1998); it is part of smaller horst and graben structures that are affected by the rift system. Consequently, the geological and sedimentary processes of the region are influenced by neotectonic activity, with impact on late Quaternary sedimentation and palaeoenvironments (Kienast et al., 2008, in press).

On Bol'shoy Lyakhovsky Island, except of heavily weathered Mesozoic bedrock with elevations of up to about $300 \mathrm{~m}$ above sea level (a.s.l.), the modern relief consists of rolling plains and low hills up to $50 \mathrm{~m}$ a.s.l. intersected by thermokarst basins and thermoerosional valleys. According to Yershov et al. (1985) the permafrost thickness reaches depths of 300-500 m. Frozen deposits of the late Quaternary are exposed at the southern coast where coastal abrasion and thawing of the ice-rich sediments form cliffs as high as $40 \mathrm{~m}$ a.s.l. which are often indented by thermo-erosional cirques (Fig. 2a). A schematic overview of the stratigraphic units at the Zimov'e River mouth on Bol'shoy Lyakhovsky Island that have been studied thus far is given in Fig. 3. According to the Quaternary stratigraphy scheme of the Dmitry Laptev Strait coasts presented by Tumskoy and Basilyan (2009), the Sartan Ice Complex belongs to the Yanskaya Suite and fills erosional structures such as valleys within the underlying older Ice Complex deposits of the Oyogoskaya Suite that formed during the Zyryan stadial and Kargin interstadial periods.

A large portion of the outcrops near the Zimov'e River consist of Kargin Ice Complex (Fig. 3) that comprises grey-brown fine-grainedsilty sand with peaty palaeosols and peat inclusions, and syngenetic ice wedges averaging 3-4 m wide. The cryostructures within the frozen sediment include coarse lens-like reticulated and banded ice $3-5 \mathrm{~cm}$ thick. The overall content of segregated ground ice reaches 60-170 wt\% (Schirrmeister et al., in press).

Ice Complex deposits accumulated in a tundra landscape when the synsedimentary growth of ice wedges shaped the land surface into a polygonal pattern. Previous studies of the last glacial Ice Complex on Bol'shoy Lyakhovsky Island revealed radiocarbon dates of in situ organic material ranging from 50 to $28.5 \mathrm{ka}$ BP. This formation, therefore, belongs to the Zyryan stadial and Kargin interstadial periods. The Ice Complex is discordantly covered by Early Holocene deposits about 9 ka BP old (Nagaoka et al., 1995; Andreev et al., 2009). Lateglacial sediments studied in exposures beneath thermokarst depressions are as old as ca $12.5 \mathrm{ka}$ BP and define the upper limit of the local sedimentary gap for Sartan deposits (Andreev et al., 2009). Despite sediment records had not been found and dated between 28.5 and $12.5 \mathrm{ka} \mathrm{BP}$, finite radiocarbon ages from this period were obtained with no large temporal gaps by bone material of the 'Mammoth fauna' (Sher et al., 2005) that have been dated to between about 26 and 16.8 ka BP (Andreev et al., 2009). The material belongs to specimens of Mammuthus primigenius, Coelodonta antiquitatis, Equus sp., and Ovibos moschatus, which were found in displaced positions on the beach or fallen from vertically-exposed Ice Complex walls.

\section{Material and methods}

The L7-07 exposure was located at the western edge of the Zimov'e River mouth directly above the coastal beach $\left(73.33086^{\circ} \mathrm{N}\right.$, $141.34423^{\circ} \mathrm{E}$; Fig. 2), and was studied in July 2007 during the joint Russian-German 'Lena - New Siberian Islands' expedition (Schirrmeister et al., 2008a). The coastal bluff was about $10 \mathrm{~m}$ high. The uppermost part was not accessible because the bluff was very steep. The lowest part was covered by muddy debris up to about $2 \mathrm{~m}$ a.s.l. The section between 2 and $6.5 \mathrm{~m}$ a.s.l. was sampled using axe and hammer to obtain frozen material in 11 samples from two subprofiles (L7-07 B: 2-4.5 m a.s.l.; L7-07 A: 4.5-6.5 m a.s.l.) taken at $0.3-0.7 \mathrm{~m}$ intervals. Along with recording sediment descriptions, gravimetric ice content was estimated immediately after thawing by relating the weight of the frozen sample to the weight of the dry sample, expressed as weight percentage (wt\%) (van Everdingen, 1998). Upon return to the laboratory the samples were freezedried, carefully manually homogenised, and split into subsamples for sedimentological and palynological analyses.

Granulometrical analyses were conducted using a laser particle analyser (Coulter LS 200) and the mass-specific magnetic 


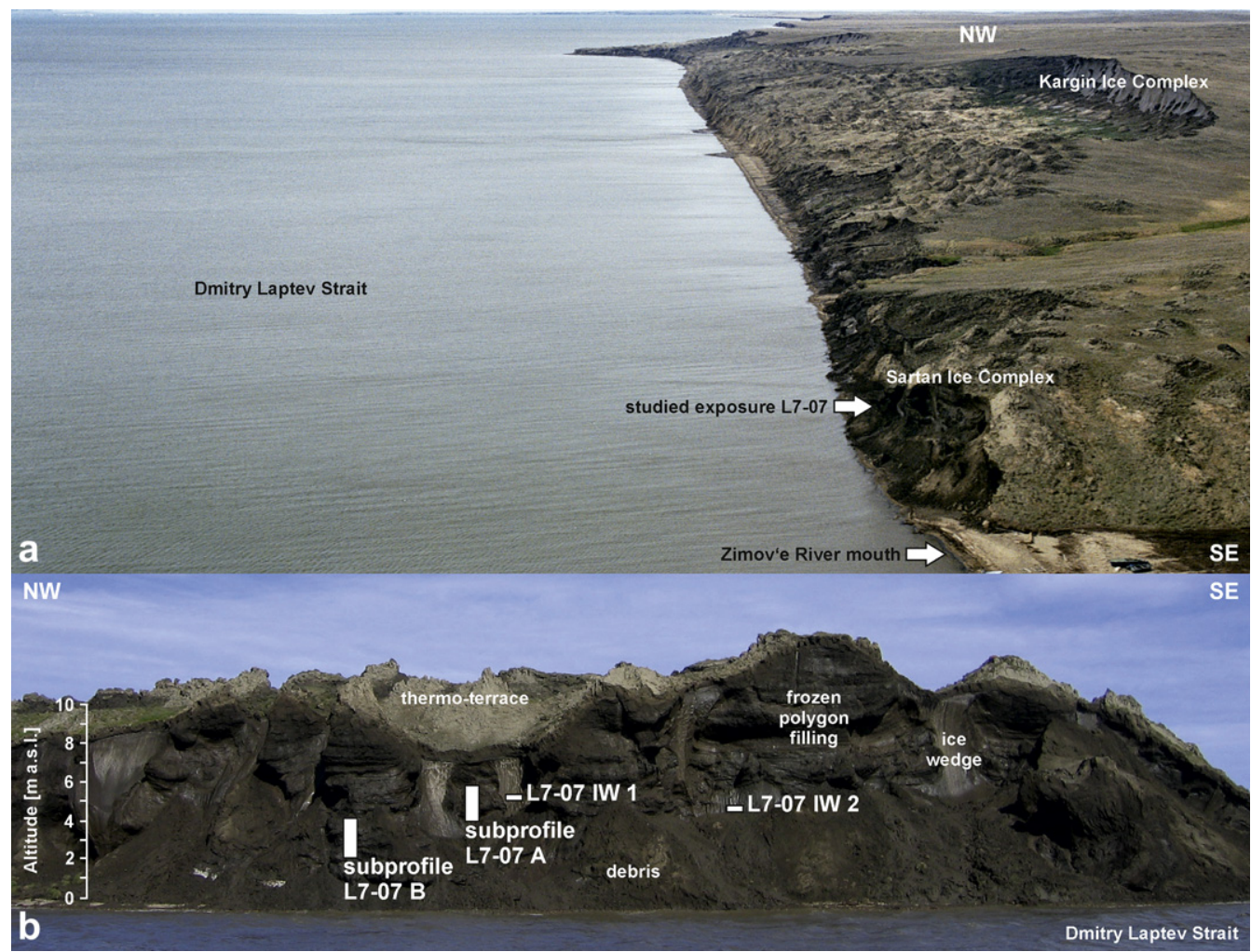

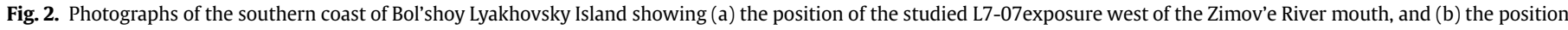
of the sampled L7-07 subprofiles and ice wedges.

susceptibility (MS) was analysed with a Bartington MS2 instrument equipped with a MS2B sensor. The values are expressed in SI units $\left(10^{-8} \mathrm{~m}^{3} \mathrm{~kg}^{-1}\right)$. The contents of total organic carbon (TOC), total carbon (TC), and total nitrogen (TN) were measured with a carbonnitrogen-sulfur (CNS) analyser (Elementar Vario EL III). The carbon to nitrogen ratio was calculated as the TOC/TN ratio. The total inorganic carbon (TIC) content was estimated as the difference between TC and TOC. The stable carbon isotope composition $\left(\delta^{13} \mathrm{C}\right)$ of TOC was analysed using a Finnigan DELTAplusXL mass spectrometer coupled with a Carlo-Erba elemental analyser. A methodological accuracy of $\pm 0.2 \%$ was determined by parallel analysis of international and internal standard reference materials. All samples were run at least in duplicate. The values are expressed in delta per mil $(\delta, \%)$ notation relative to the Vienna Pee Dee Belemnite (VPDB) Standard.

Two syngenetic ice wedges of the exposure were sampled using ice screws in horizontal transects across the central part of exposed ice (L7-07 IW 1 at about $5 \mathrm{~m}$ a.s.l.; L7-07 IW 2 at about $4 \mathrm{~m}$ a.s.l.; Fig. $2 \mathrm{~b})$ for stable oxygen $\left(\delta^{18} \mathrm{O}\right)$ and hydrogen $(\delta \mathrm{D})$ isotopes. The maximal width of both ice wedges was only about $2-3 \mathrm{~m}$, which is rather small compared to the width of wedges from the Kargin Ice Complex elsewhere. Additionally, supernatant water from the sediment samples, i.e. from thawed texture ice, was sampled. The ice samples were stored cool and analysed afterwards by equilibration technique using a mass spectrometer (Finnigan MAT Delta-S) with reproducibility derived from long-term standard measurements of $1 \sigma$ better than $\pm 0.1 \%$ o (Meyer et al., 2000). All samples were run at least in duplicate. The values are given as $\delta, \%$ relative to the Vienna Standard Mean Ocean Water (VSMOW) Standard.

Radiocarbon dating using the accelerator mass spectrometry (AMS) facilities at the Leibniz Laboratory for Radiometric Dating and Stable Isotope Research (Kiel, Germany; Grootes et al., 2004) was carried out on fossil plant material selected from four sediment

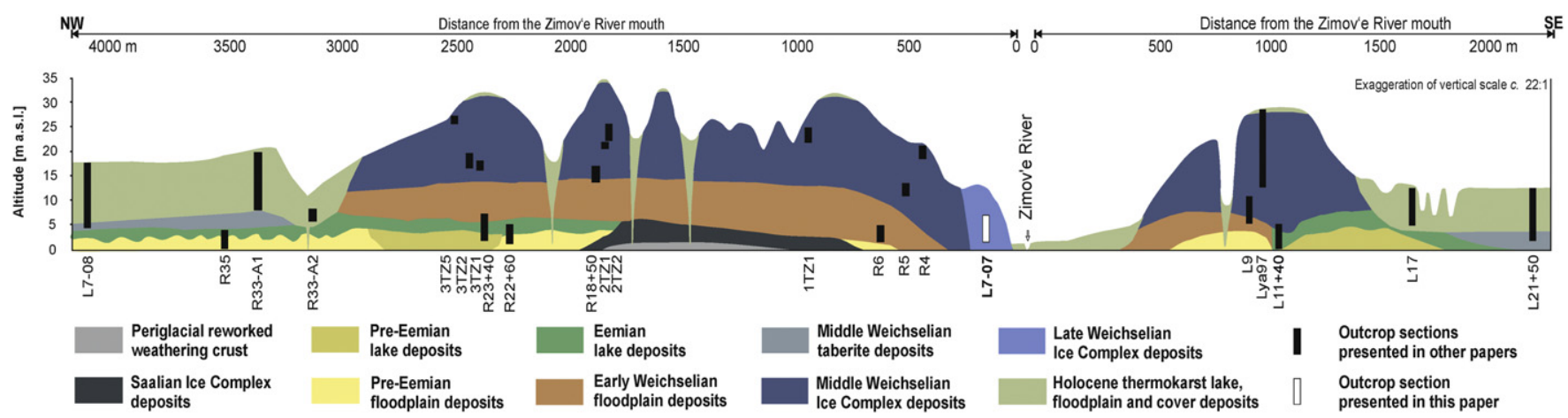

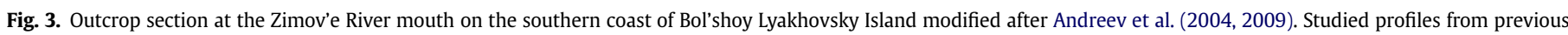

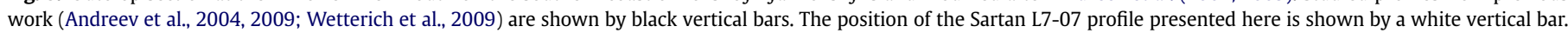


Table 2

AMS-measured radiocarbon ages of plant remains and bone material in samples of the Sartan sequences from Bol'shoy Lyakhovsky (L7-07).

\begin{tabular}{|c|c|c|c|c|c|}
\hline Sample $\mathcal{N} \underline{\circ}$ & $\operatorname{Lab} \mathcal{N} \underline{\circ}$ & Material & $\begin{array}{l}\text { Elevation } \\
{[\mathrm{m}, \text { a.s.l.] }}\end{array}$ & \multicolumn{2}{|c|}{$\begin{array}{l}\text { Radiocarbon ages } \\
{\left[{ }^{14} \mathrm{C} \text { a BP }\right]}\end{array}$} \\
\hline L7-07-02 & KIA-41332 & Plant remains & 6 & 22320 & $+240 /-230$ \\
\hline L7-07-04 & KIA-41333 & Plant remains & 5 & 25740 & $+340 /-320$ \\
\hline L7-07-07 & KIA-41334 & Plant remains & 4 & 23920 & \pm 180 \\
\hline L7-07-10 & KIA-41335 & Plant remains & 2.6 & 24420 & $+210 /-200$ \\
\hline L7-07-03 & KIA-41336 & $\begin{array}{l}\text { in situ bone } \\
(\text { Equus sp., MC III })^{\mathrm{a}}\end{array}$ & 1.5 & 29390 & \pm 200 \\
\hline L7-07-05 & KIA-41337 & $\begin{array}{l}\text { Displaced bone } \\
(M \text {. primigenius, } \\
\text { fibula, distal frag. })^{a}\end{array}$ & & 37440 & $+460 /-430$ \\
\hline
\end{tabular}

${ }^{a}$ Identification of the dated bone material by T. Kuznetsova (Moscow State University, Department of Palaeontology).

samples, and on two bone samples (Table 2 ). All radiocarbon dates through this paper are reported as uncalibrated ages.

For palynological analyses, two-gram subsamples of dry sediment were treated using standard procedure (Fægri and Iversen, 1989). Two Lycopodium spore tablets were added to each subsample in order to calculate total pollen and spore concentration. Pollen residues mounted in glycerin were analysed under the light microscope with a $\times 400$ magnification. The identification of the pollen and spores was performed using reference pollen collections and pollen atlases (Reille, 1992, 1995, 1998). The microscopic analyses revealed sufficiently high pollen concentration and sufficiently good preservation of pollen grains to allow the counting of more than 300 terrestrial pollen grains per sample. Taxa percentages were calculated based on setting the total sum of pollen as equal to $100 \%$. Results of pollen analyses are displayed in a diagram produced with the Tilia/TiliaGraph software (Grimm, 1991, 1993).

\section{Results}

In subprofile L7-07 B, the lowermost horizon (2.0-2.8 $\mathrm{m}$ a.s.l.) above the debris consisted of light-brown to grey silt containing roots and plant detritus. The cryostructure was banded with diagonal lenses between ice bands (ice content of $35 \mathrm{wt} \%$ ). Higher up, at $3 \mathrm{~m}$ a.s.l., the silt colour changed to dark grey; the cryostructure was coarse lens-like reticulated, and exhibited a much higher ice content of 117 wt\%. Between $3.5 \mathrm{~m}$ and $5 \mathrm{~m}$ a.s.l., irregularly-bedded alternations of finer and coarser light-brown to grey-brown silt with plant remains and peat inclusions were found with a fine lens-like cryostructure (ice content 87 wt\%). A peaty layer, which continued horizontally through the entire exposure, was sampled at 4.5 and $4.7 \mathrm{~m}$ a.s.l. Subprofile L7-07 A started in the same peaty horizon at $4.5 \mathrm{~m}$ a.s.l. (ice content $113 \mathrm{wt} \%$ ). Above the peaty horizon, the sediments were characterised by grey-brown to light-brown bedded silts. Interstratified layers of fine plant detritus that marked ripple bedding. The cryostructure was ice-banded and fine lens-like to lattice-like between ice bands (ice content $56 \mathrm{wt} \%$ ). The overall L7-07 sediment properties are characterised by medium- to coarse-grained silt and a rather constant sediment source, as indicated by steady magnetic properties with MS values of around $2510^{-8} \mathrm{~m}^{3} \mathrm{~kg}^{-1}$ (Fig. 4). The bimodal grain size distribution (Fig. 5) together with the observed ripple bedding point to accumulation with flowing and stagnant water on a river floodplain. The TOC content reaches up to about $5 \mathrm{wt} \%$ in the peat layer between 4.5 and $5 \mathrm{~m}$ a.s.l., while TIC content remains below $0.5 \mathrm{wt} \%$ in all samples. Except for the lowermost sample, the TOC/TN ratios show a rather low variation of between about 9 and 12 (Fig. 4). The highest TOC/TN ratios occur in peaty samples located between 4.5 and $5 \mathrm{~m}$ a.s.l., pointing to less decomposed organic matter in these sediments. The $\delta^{13} \mathrm{C}$ of TOC is almost stable, with values in the lower L7-07 B subprofile of around $-26.5 \%$; values increase slightly, by about one permil, in the upper L7-07 A subprofile (Fig. 4).

The stable water isotope composition of texture ice shows broad variations from about -32 to $-22 \%$ for $\delta^{18} \mathrm{O}$ and -245 to $-194 \%$ for $\delta \mathrm{D}$ (Table 3); with lower (more negative) values in the upper subprofile L7-07 A as compared to subprofile L7-07 B (Fig. 4).

The oldest age of about $37.4 \mathrm{ka} \mathrm{BP}$ is not included in further discussions because it comes from a mammoth bone (distal fibula fragment) found on the debris apron below the exposure.

Radiocarbon dates of horse bone (metacarpal bone, MC III) found in situ below the sampled section revealed an age as old as about 29.4ka BP. Both subprofiles dated by plant material (subprofile L7-07 A: 25.7 to 22.3 ka BP; subprofile L7-07 B: 24.4 to 23.9 ka BP) accumulated during the Sartan stadial. The overall period covered by the exposure L7-07 ranges from 25.7 to 22.3 ka BP (Table 2). The apparent same age range of both subprofiles at different heights above sea level is likely connected to cryoturbation and to the sample positions within each polygon filling. Considering that in syngenetic ice-wedge polygons the sediments accumulate contemporary with the ice wedge growth, the

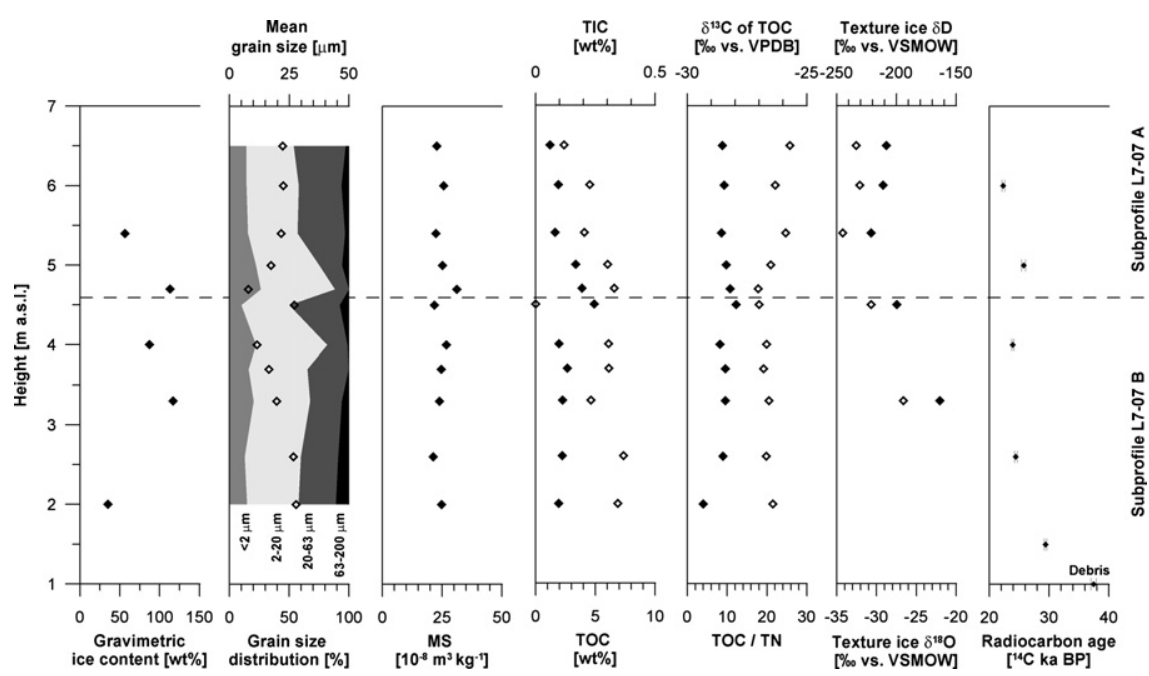

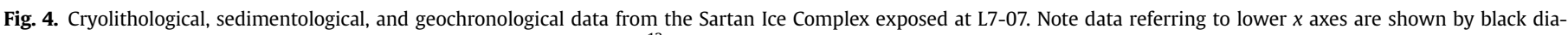
monds and data referring to upper $x$ axes (mean grain size, TIC values, $\delta^{13} \mathrm{C}$ of TOC values, texture ice $\delta \mathrm{D}$ ) are shown by open diamonds. 

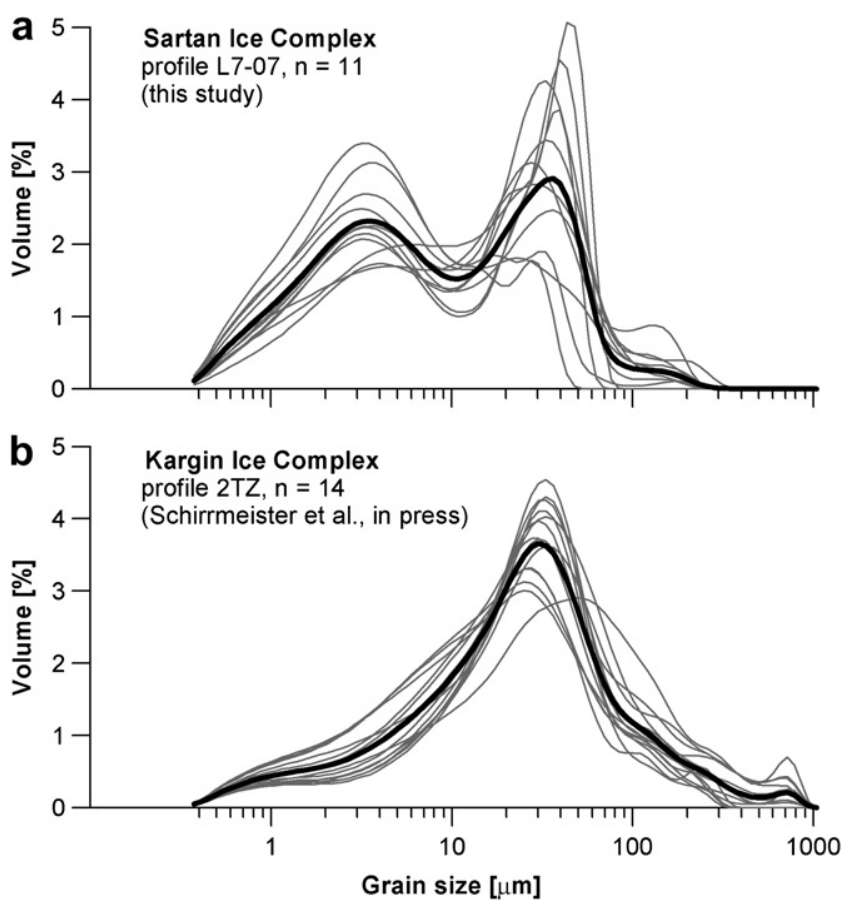

Fig. 5. Typical grain size distributions: (a) in Sartan Ice Complex deposits, and (b) in an example of Kargin Ice Complex deposits on Bol'shoy Lyakhovsky Island. Bold curves delineate the mean values.

sediment horizons are commonly bend up towards the ice wedge; therefore same-aged samples at the margin and the centre of a polygon appear at different heights.

Two ice wedges from the L7-07 section revealed very similar stable water isotope compositions, with narrow ranges from about -38 to $-36 \%$ for $\delta^{18} \mathrm{O}$ (IW $1: \delta^{18} \mathrm{O}_{\text {mean }}$ of $-37.43 \%$; IW 2 : $\delta^{18} \mathrm{O}_{\text {mean }}$ of $-36.91 \%$ ) to -295 to $280 \%$ for $\delta \mathrm{D}$ (IW $1: \delta \mathrm{D}_{\text {mean }}$ of $-292.3 \%$; IW 2: $\delta D_{\text {mean }}$ of $-288.7 \%$ ). The mean deuterium excess $\left(\mathrm{d}=\delta \mathrm{D}-8 \delta^{18} \mathrm{O}\right.$; Dansgaard, 1964) reaches $7.1 \%$ for IW 1 and $6.7 \%$ for IW 2. Despite the low number of samples, the regression in a $\delta^{18} \mathrm{O}-\delta \mathrm{D}$ co-isotope plot (Fig. 6a) shows a slope of 7.3 and an intercept of -18.5 for IW 1 with $r^{2}=0.93$, and a slope of 6.3 and an intercept of -58 for IW 2 with $r^{2}=0.88$ (Table 3 ).

Table 3

Stable water isotope $\left(\delta^{18} \mathrm{O}, \delta \mathrm{D}\right.$, and d excess) minimum, mean, and maximum values, standard deviations, and slopes and intercepts in the $\delta^{18} \mathrm{O}-\delta \mathrm{D}$ diagram (Fig. 6a) for both sampled ice wedges and for the texture ice samples.

\begin{tabular}{llccc}
\hline & & L7-07 IW 1 & L7-07 IW 2 & Texture ice \\
\hline$\delta^{18} \mathrm{O}[\%$ o $]$ & Mean & -37.43 & -36.91 & -27.63 \\
& Max & -36.78 & -35.83 & -22.05 \\
& Min & -37.76 & -37.98 & -30.69 \\
& Std. dev. & 0.32 & 0.71 & 2.97 \\
$\delta \mathrm{D}[\%$ \% $]$ & Mean & -292.3 & -288.7 & -224.9 \\
& Max & -287.9 & -280.2 & -194.1 \\
& Min & -296.0 & -294.6 & -244.9 \\
& Std. dev. & 2.4 & 4.8 & 17.2 \\
$\mathrm{~d}[\%$ o $]$ & Mean & 7.1 & 6.7 & -3.9 \\
& Max & 7.9 & 11.6 & 2.5 \\
& Min & 6.1 & 4.2 & -17.6 \\
$\mathrm{n}$ & Std. dev. & 0.7 & 2.1 & 7.1 \\
Slope & & 6 & 8 & 5 \\
Intercept & & 7.3 & 6.3 & 5.7 \\
$\mathrm{r}^{2}$ & & -18.5 & -58 & -66.7 \\
\hline & & 0.93 & 0.88 & 0.98 \\
\hline
\end{tabular}

The pollen diagram is subdivided into two parts; subprofile L707-A and subprofile L7-07-B (Fig. 7). In total, 38 pollen and spore taxa, and 5 types of non-pollen palynomorphs (NPPs) were identified. The pollen spectra of the lower L7-07-B subprofile are characterised by the dominance of herbaceous pollen; Poaceae (up to $50 \%$ ), Cyperaceae (up to $20 \%$ ), Artemisia (up to $15 \%$ ), Ranunculaceae (up to 15\%), Caryophyllaceae (up to $15 \%$ ), and Brassicaceae (up to $6 \%$ ). The percentage of arboreal pollen does not exceed $10 \%$. Conifers are mostly represented by reworked Pinus s/g Haploxylon (max 7.4\%). Shrubs are reflected by Betula nana s.l., Salix, and Duschekia (Alnus) fruticosa. Spores of high vascular plants belong to Polypodiophyta and Lycopodiophyta (Selaginella rupestris, Lycopodium, Huperzia). Selaginella rupestrisis not present in abundance (max. $2.7 \%$ av. 1\%). Spores of Sphagnum are found in almost every sample, but in low abundance. Zygospores of Zygnemataceae (Zygnema-type) represent NPPs and occur constantly in subprofile L7-07 B.

Samples from the lowermost part of L7-07-A are characterised by a sharp increase in pollen concentration $\left(35-4010^{3}\right.$ grains gram $^{-1}$ ) with a high abundance of Poaceae pollen (75-76\%). Pollen of Cyperaceae (up to 24\%), Caryophyllaceae (up to 10\%), Artemisia (up to $9 \%$ ), and Brassicaceae (up to $8 \%$ ) dominate among herbaceous taxa. The arboreal pollen percentage reaches $20 \%$. Biodiversity and percentages of shrub taxa slightly increase in this subprofile. The percentage of Selaginella rupestris is, on average, 0.9\%. NPPs are mostly represented by Zygnemataceae. Stomata of reworked Pinaceae (Pinus and Larix) occur at $5.4 \mathrm{~m}$ a.s.l.

\section{Discussion}

\subsection{The Sartan Ice Complex on Bol'shoy Lyakhovsky Island}

Permafrost-related features in periglacial landscapes depend on freezing and thawing, and are therefore highly vulnerable to climate variations and subsequent changes in the depositional and hydrological regimes. Permafrost degradation and periglacial landscape dynamics greatly influence the preservation of distinct stratigraphic elements in certain landscape compartments. In other words, changes in sedimentation and preservation conditions define the later accessibility of sediment sequences that formed under specific past environmental situations. On Bol'shoy Lyakhovsky Island at the Zimov'e River mouth Sartan deposits are exposed at the same height level as older deposits of the Kargin or even older sequences (Fig. 3). Therefore, a change in Ice Complex accumulation areas from flat plains during the Kargin until about $29 \mathrm{ka}$ BP, to erosional landforms like valleys and basins during the Sartan is assumed and recorded on the island. According to Tumskoy (2004) and Tumskoy and Basil'yan (2009), the Ice Complex accumulation during the Sartan period in the Yana lowland and the region of the Dmitry Laptev Strait differed from the previous Kargin period. This is explained by a lowered erosion base due to LGM sea level low stand. Consequently, existing rivers and streams incised into sediments especially at their lower reaches, and new branches were formed by cutting into older sediments. Sartan Ice Complex in close vicinity (up to several tens of kilometres) to its source region (e.g. Mountain ranges, Schirrmeister et al., in press) developed above Kargin interstadial Ice Complex depending on the less active erosion in the upper reaches of streams and the inclination of the foreland plain. Therefore, in less inclined areas like the forelands of the Kharaulakh Mountains (Bykovsky Peninsula) and Pronchishev Mountains (Mamontov Klyk) Sartan Ice Complex accumulated above Kargin interstadial deposits. On Bol'shoy Lyakhovsky, the hinterland elevations are also rather close to the Sartan stadial Ice Complex but the relief inclination is higher, i.e. erosion was more intense during the Sartan. 
a

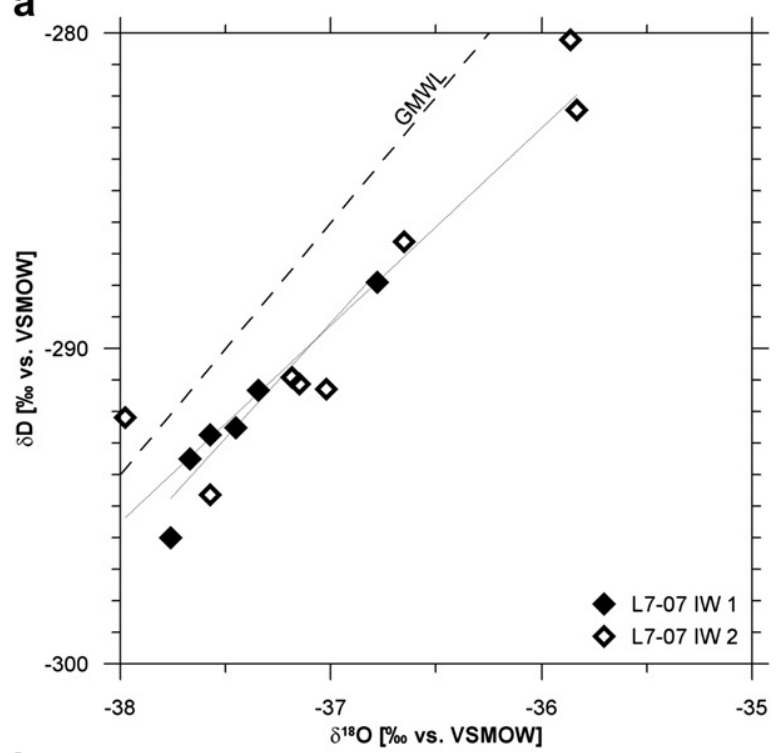

b

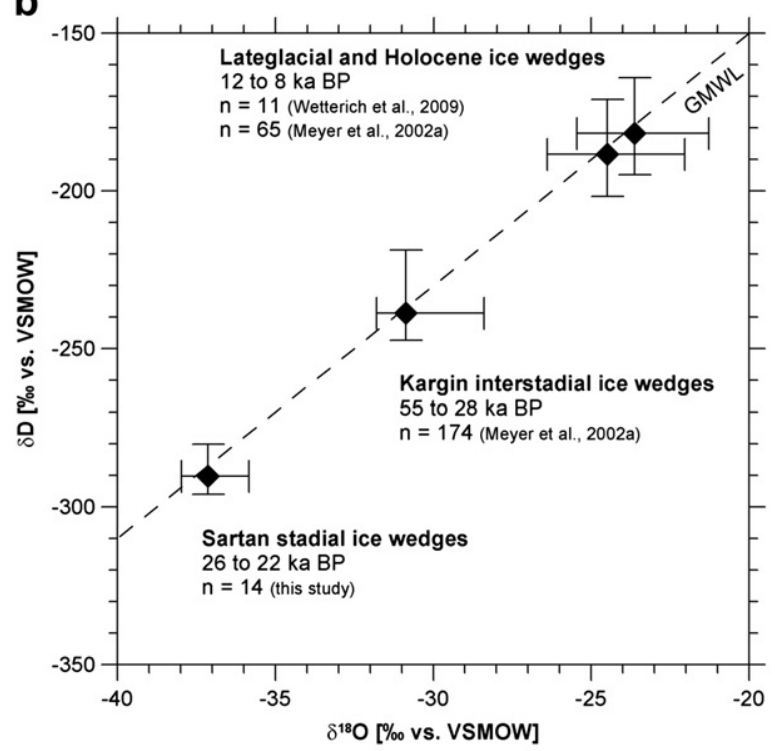

C

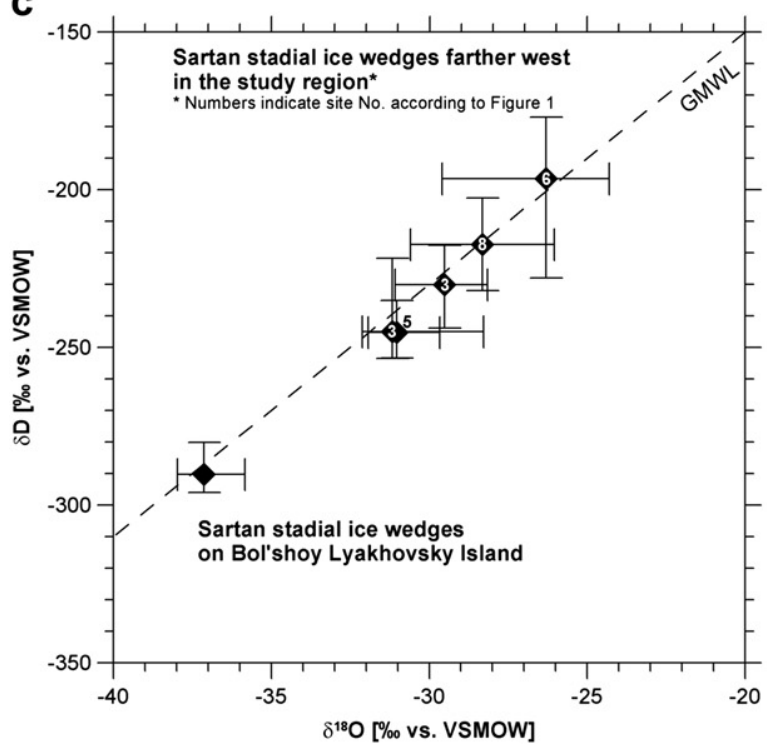

According to the assumed change in the hydrological system, prevailing deposition moved from plain to valley positions leading here to Sartan Ice Complex formation with specific cryolithological, ice wedge and sediment properties.

The sedimentological and cryolithological records of profile L7-07 prove continuous alluvial Ice Complex accumulation of fine-grained material in a valley position between about 29.4 and $22.3 \mathrm{ka}$ BP. Local re-deposition of fine-grained material is assumed according to the Ice Complex formation hypothesis put forward by Schirrmeister et al. (in press). The sediment source remained stable as inferred from uniform MS values and grain size parameters (Fig. 4). Floodplain conditions are assumed and confirmed by ripple bedding and bimodal grain size distributions, and clearly differ from Kargin Ice Complex characteristics (Fig. 5). The biogeochemical signature of the frozen deposits with low TOC contents (except for one peat layer), relatively low TOC/TN ratios, and almost stable $\delta^{13} \mathrm{C}$ of TOC point to low accumulation and more advanced decomposition of organic matter as well as slow soil formation under dry and aerobic conditions. As in most Ice Complex deposits, intrasedimental ice structures are characterised by banded and lens-like reticulated patterns indicating poor drainage conditions and a near-surface permafrost table during accumulation and freezing (Dostovalov and Kudryavtsev, 1967; French and Shur, 2010). The stable water isotopes of texture ice are more depleted (i.e. more negative) in the upper subprofile L7$07 \mathrm{~A}$ if compared to the lower subprofile L7-07 B (Fig. 4). Following Schwamborn et al. $(2006,2008)$ changes in texture-ice stable water isotope composition might indicate environmental change that influenced the ground-ice formation.

A continuous growth of syngenetic ice wedges reflects sufficient meltwater supply for their formation, at least in low ground landforms like valley or basin bottoms. Ice-wedge stable water isotope composition as a proxy for winter temperatures (e.g. Meyer et al., 2002a) reflects the coldest conditions obtained so far from late Pleistocene ice wedges on Bol'shoy Lyakhovsky Island, and elsewhere in the Laptev Sea region. The mean Sartan ice-wedge $\delta^{18} \mathrm{O}$ value of about $-37 \%$ is about $6 \%$ lower than those of Kargin ice wedges and about $13 \%$ lower than those of Holocene ice wedges on Bol'shoy Lyakhovsky Island (Fig. 6b). According to Kuznetsova (1998) the influence of modern winter moisture transported by the Atlantic Westerlies and the Pacific Easterlies meets in the Laptev Sea region between $130^{\circ} \mathrm{E}$ and $150^{\circ} \mathrm{E}$. The winter precipitation on Bol'shoy Lyakhovsky Island has been assumed to be influenced by moisture from the North Pacific Ocean as indicated by characteristic d-excess values below $10 \%$ (Meyer et al., 2002a).

The palynological L7-07 complex dated to the early Sartan stadial reflects the existence of an impoverished variant of tundrasteppe vegetation (termed 'cold tundra-steppe' by Sher et al. (2005)). The characteristics of arctic tundra-steppe (cryophyte steppe) include prevalent graminoids (grasses and sedges), wormwoods, and other herbs versus trees and shrubs (Yurtsev, 2001). The dominance of graminoids, together with abundant Artemisia, and low percentages of Ericales (indicator of wet plant communities) in the L7-07 pollen spectra point to rather dry climatic conditions. Evidence of an extremely cold climate is given

Fig. 6. Stable water-isotope composition of ice wedges: (a) from the Sartan Ice Complex L7-07 exposure, compared to (b) previously studied older and younger ice wedges from Bol'shoy Lyakhovsky Island (Meyer et al., 2002a; Wetterich et al., 2009), and compared to (c) regional Sartan stadial records where available according to Fig. 1: site 3 - Bykovsky Peninsula (IW MKh-4.13, $n=36,24$ ka BP and IW MKh-00, $n=35,20$ ka BP; Meyer et al., 2002b); site 5 - Mamontov Klyk (IW MAK-17, $n=33,22$ ka BP; Meyer, unpublished data); site 6 - Cape Sabler (SAO-1, IW-3, $n=26,<18 \mathrm{ka} B$ P, Derevyagin et al., 1999); site 8 - Lake Labaz (LAB4/94, LAB5/94, LAB9/95, $n=9,<20$ ka BP, Siegert et al., 1999). Data are shown with respect to the Global Meteoric Water Line (GMWL) in which fresh surface waters are correlated on a global scale (Craig, 1961). 


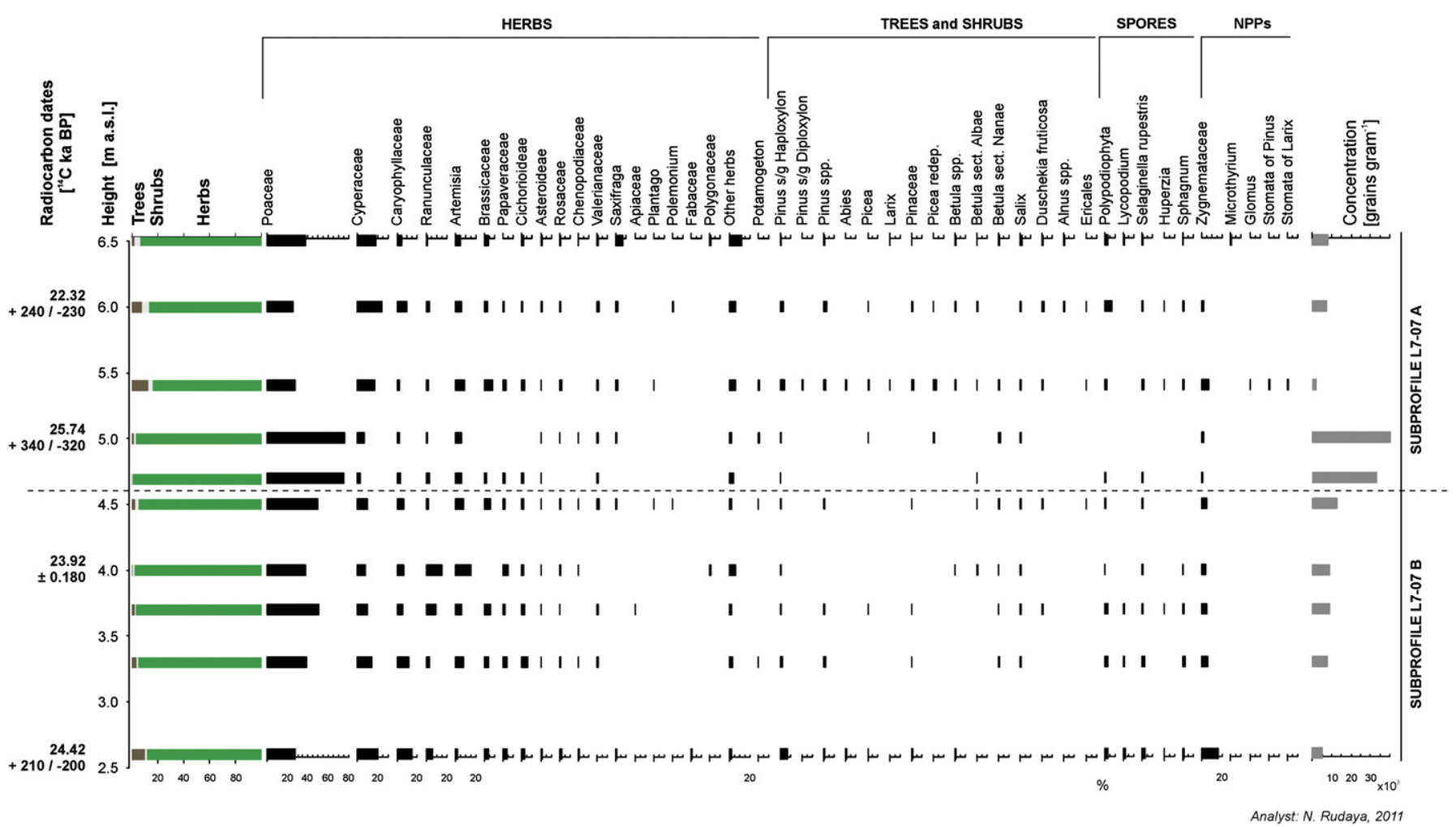

Fig. 7. Percentage diagram presenting pollen and non-pollen palynomorph records from the Sartan Ice Complex L7-07 exposure.

by the dominance of Poaceae over Cyperaceae pollen. The large amount of Caryophyllaceae, Brassicaceae, and Papaveraceae, which are arctic pioneer taxa characteristic of northernmost vascular plant communities in polar deserts (Kienast et al., 2005, 2008, in press), confirms this interpretation. Selaginella rupestris occurs in disturbed and dry habitats, and its spores occur commonly in Sar$\tan$ spectra. This species is an important indicator of steppe-like environments in the Arctic (Andreev et al., 2002a, 2009, in press). However, the low abundance of $S$. rupestris spores in both L7-07 subprofiles is close to the average percentage of these spores $(0.7 \%)$ in modern surface samples from northeast Siberian tundra communities (Edwards et al., 2000; Lozhkin, 2002). Such low abundance is probably caused by local peculiarities like poor drainage of the studied site. The continuous presence of the cosmopolitan green algae family Zygnemataceae, which prefers stagnant, shallow, and mesotrophic freshwater habitats (van Geel and van der Hammen, 1978) or fluvial surface sediment (Medeanic, 2006), likely indicates the occurrence of shallow polygon ponds on the floodplain terrace of the Zimov'e River valley. In summary, climatic conditions more arid than today's are assumed from the pollen data.

When the Sartan pollen records are compared with older Kargin records and younger Lateglacial counterparts (Andreev et al., 2009; Wetterich et al., 2009), the following differences are evident. Both the Kargin and the Lateglacial pollen data sets exhibit higher pollen concentrations, likely indicating more dense plant cover and higher pollen production during both periods. The grass-sedge-dominated open vegetation during the Kargin until about $29 \mathrm{ka} \mathrm{BP}$ reflects some amelioration of the harsh environmental conditions that prevailed during the Zyryan stadial. Reworked Pinaceae pollen in lower numbers and the presence of Salix are characteristic of the Kargin pollen records (Andreev et al., 2009). A herb- and shrub-dominated Lateglacial vegetation is reflected in pollen data from Bol'shoy Lyakhovsky after the Sartan stadial. Betula sect. Nanae, B. sect. Albae, and
Duschekia (Alnus) fruticosa pollen mirror warming climate conditions (Andreev et al., 2009; Wetterich et al., 2009).

\subsection{Other Sartan records in the Laptev Sea region}

The LGM as defined by the maximal ice sheet extent corresponding to the last maximal cooling event on a global scale, peaked between about 21 and 20 ka BP (Svendsen et al., 2004; Miller et al., 2010). Regional evidence from East Siberia provided by various proxy data from synchronously-formed permafrost indicates spatial and temporal differences, even though it is rarely reported that the entire last glacial period is completely represented in such deposits. The L7-07 palaeoenvironmental data from Bol'shoy Lyakhovsky Island can be put into regional context by comparing them to other regional Sartan Ice Complex records (Fig. 1).

\subsubsection{Lower Yana River}

The Sartan Ice Complex that formed in the Yana River valley (site 2 in Fig. 1; Pitul'ko et al., 2007) continues above the late Kargin Ice Complex, continuously exposing the transition over several decametres-thick sequences from the interstadial to the stadial. The sequence starts with the oldest finite radiocarbon dates of about $34.7 \mathrm{ka} \mathrm{BP}$; older (infinite) dates have also been obtained (for overview see Pitul'ko and Pavlova, 2010). Zyryan stadial sediments are not exposed. Detailed pollen- and plantmacrofossil-based numerical reconstructions of the mean temperature in July $\left(\mathrm{T}_{\text {July }}\right)$, the warmest month, and mean annual precipitation ( $P_{\text {Annual }}$ ) from the Ice Complex exposed at the lower Yana River bank for the period in question, from the terminal Kargin to the early Holocene (Boreal), have been published by Pitul'ko et al. (2007). The terminal Kargin vegetation records dated to 28 to $23 \mathrm{ka} \mathrm{BP}$ are dominated by xerophilic taxa, indicating summer temperatures slightly warmer than those of today $\left(\mathrm{T}_{\text {July }}\right.$ 
up to $2{ }^{\circ} \mathrm{C}$ warmer than today), and varying mean annual precipitation. The dry and relatively warm summer conditions of a continental climate that promote a tundra-steppe environment are assumed. According to Pitul'ko et al. (2007), changing climate and environmental conditions at the transition from the Kargin interstadial to the Sartan stadial (after $23 \mathrm{ka} \mathrm{BP}$ ) are reflected by decreased summer temperatures ( $\mathrm{T}_{\text {July }}$ as low as $5{ }^{\circ} \mathrm{C}$ cooler than today) and decreased $\mathrm{P}_{\text {Annual. }}$. If comparing the Sartan pollen records from the lover Yana River site to the L7-07 pollen data predominance of grass pollen over sedges during the Sartan stadial was found in both records. However, they differ by the low concentration of $S$. rupestris, the absence of green algae colonies of Pediastrum and Botryococcus, and the relatively high abundance of Zygnemacysts in L7-07. These differences are likely explainable by differences in local landscape conditions.

\subsubsection{Bykovsky Peninsula}

Valley-filling Sartan sediments are described on Bykovsky Peninsula (site 3 in Fig. 1; Grosse et al., 2007), but Sartan Ice Complex isalso exposed on top of the Zyryan and Kargin Ice Complex between 22 and $35 \mathrm{~m}$ a.s.l. (Schirrmeister et al., 2002b). The latter indicates continuous accumulation in the northern foreland plain of the Kharaulakh Ridge starting in the Zyryan stadial over the following stadial-interstadial-stadial transitions. An almost complete sequence of Sartan permafrost deposits was obtained from Bykovsky Peninsula (site 3 in Fig. 1), and intensively studied for its palaeontological content (pollen by Andreev et al., 2002a; testate amoebae by Bobrov et al., 2004; plant macrofossils by Kienast et al., 2005; fossil insects and mammal bones by Sher et al., 2005; and ostracods by Wetterich et al., 2005). Sedimentological and ground ice studies have been provided by Meyer et al. (2002b), Schirrmeister et al. (2002b), and Siegert et al. (2002). The sediments representing the Sartan period (28-12 ka BP; unit C in Schirrmeister et al., 2002b) are characterised as badly sorted silty sand with low TOC contents, low $\mathrm{C} / \mathrm{N}$ ratios and high $\delta^{13} \mathrm{C}$ values, and reflect relatively dry, aerobic conditions with reduced biological activity. On Bykovsky Peninsula, stable water isotope data of ice wedges in the upper part of the Ice Complex (Meyer et al., 2002b) represent the Sartan period. Two syngenetic ice wedges (each $3.5 \mathrm{~m}$ wide) were dated by organic material from surrounding sediments to about $24 \mathrm{ka} \mathrm{BP} \mathrm{(MKh-4.13)} \mathrm{and} 20 \mathrm{ka}$ BP (MKh-00) (Meyer et al., 2002b). Their mean isotopic values reach about $-31 \%$ and $-29.5 \%$ for $\delta^{18} \mathrm{O}$, and about $-222 \%$ and $-218 \%$ for $\delta$ D, respectively (Fig. 6c, Table 4). The ice-wedge data may reflect that winter temperatures in the Sartan stadial were cold, but not colder than during the preceding Kargin interstadial. As assumed from the ice-wedge data both periods experienced generally cold and stable winter climate conditions until about 20 ka BP (Meyer et al., 2002b). The isotopic composition of Sartan ice wedges at Bykovsky Peninsula gives no indication of a LGM winter temperature minimum. The moisture source of LGM winter precipitation for Bykovsky Peninsula has been assumed to derive from lower latitudes of the Atlantic Ocean also characterised by rather low d-excess values (Meyer et al., 2002b; Meyer, 2003).
The combined descriptive reconstruction of Sartan environments from about 24 to $15 \mathrm{ka}$ BP mirrors the coldest type of tundrasteppe vegetation (Sher et al., 2005) with low bioproductivity (scarce plant cover and low pollen production) persisting under stable, extremely cold and dry conditions (Schirrmeister et al., 2002b). The grass-dominated vegetation, however, enabled the survival of the 'Mammoth fauna' as proven by dated bone material (Sher et al., 2005). Palaeobotanical records prove a mosaic-like local vegetation of arctic species coexisting with aquatic, littoral, meadow, and steppe taxa, reflecting an extremely continental, arid climate. Persisting thermophilic plant taxa indicate summers that were warmer than at present (Kienast et al., 2005). Also, according to fossil insect data presented by Sher et al. (2005), this interpretation contradicts the pollen- and plant-macrofossil-based summer conditions reconstructed by Pitul'ko et al. (2007) from the lower Yana River as described in the previous section. A disappearance of steppe (and xerophilic) Coleoptera (beetle) species in the Bykovsky Peninsula records corresponds to an increase of cold-adapted Arctic tundra inhabitants between about 24 and $15 \mathrm{ka}$ BP (Sher et al., 2005). The following Lateglacial stage after about $15 \mathrm{ka} \mathrm{BP,} \mathrm{in}$ which the Sartan terminates, is characterised by pronounced changes towards warmer and wetter conditions.

\subsubsection{Lena Delta}

The known Sartan Ice Complex records from the third terrace of the Lena Delta were obtained from 1 to $2 \mathrm{~m}$ thick horizons that preserve the late stage of the stadial at about 17 ka BP (site 4 in Fig. 1; Schirrmeister et al., 2003; Wetterich et al., 2008). On Kurungnakh Island, large portions of the early and middle Sartan deposits are lacking, while preserved late Sartan sediments are considered to be buried deposits of an erosional surface of the Ice Complex sequence (Wetterich et al., 2008). The Sartan sediments are organic-poor sandy silts. Stable water isotope data from Sartan ice wedges have not been obtained. Pollen and plant macrofossil data reflect scarce tundra-steppe vegetation indicated by very low pollen concentrations due to low pollen production during the Sartan stadial. The latter is characterised by steppe-like Poaceae communities with some Caryophyllaceae, Asteraceae, and Cichoriaceae (Schirrmeister et al., 2003).

\subsubsection{Cape Mamontov Klyk}

The Sartan record from the western Laptev Sea coast was obtained from Cape Mamontov Klyk (site 5 in Fig. 1; Schirrmeister et al., 2008b). This Ice Complex formed in the foreland plain north of the Pronchishchev Ridge, and comprises a continuous Sartan sequence up to $20 \mathrm{~m}$ thick and dated from 27.2 to $14.5 \mathrm{ka} \mathrm{BP}$ (Schirrmeister et al., 2008b). Yet unpublished data stable water isotope data from a syngenetic ice wedge (MAK-IW-17, $3.2 \mathrm{~m}$ wide) show mean values of $-31 \%$ for $\delta^{18} \mathrm{O}$ and $-245 \%$ for $\delta \mathrm{D}$ (Fig. $6 \mathrm{c}$, Table 4, personal communication $\mathrm{H}$. Meyer, AWI Potsdam, Germany). The corresponding sediment unit was dated to about 22 ka BP (unit C, subprofile 15 in Schirrmeister et al., 2008b). These ice-rich Ice Complex sediments are badly sorted sandy silt

Table 4

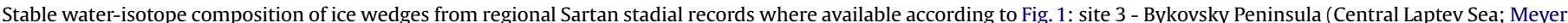

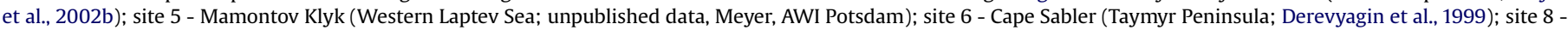
Lake Labaz (Taymyr Peninsula; Siegert et al., 1999).

\begin{tabular}{|c|c|c|c|c|c|c|c|}
\hline Site $\mathcal{N} \subseteq$ & Location & ID & Age [ka BP] & $\mathrm{n}$ & $\delta^{18} \mathrm{O}[\%]$ & $\delta \mathrm{D}[\%]$ & $\mathrm{d}[\% \mathrm{oo}]$ \\
\hline 1 & Bol'shoy Lyakhovsky & L7-07 IW 1, IW-2 & 26 to 22 & 14 & -37.13 & -290.2 & 6.8 \\
\hline 3 & Bykovsky Peninsula & IW MKh-4.13 & 24 & 36 & -31.17 & -245 & 4.4 \\
\hline 3 & Bykovsky Peninsula & IW MKh-00 & 20 & 35 & -29.52 & -230.2 & 5 \\
\hline 5 & Mamontov Klyk & IW MAK-17 & 22 & 33 & -31.04 & -245.3 & 3 \\
\hline 6 & Cape Sabler & SAO-1, IW-3 & $<18$ & 26 & -26.30 & -196.5 & 13.9 \\
\hline 8 & Lake Labaz & LAB- $4 / 94,-5 / 94,-9 / 95$ & $<20$ & 9 & -28.32 & -217.4 & 9.2 \\
\hline
\end{tabular}


intersected by weakly developed buried cryosols with higher organic content, peat and plant detritus inclusions.

Older Zyryan and Kargin sediments belong to a sandy fluvial facies. The Sartan pollen data mirror Poaceae-dominated vegetation including Cyperaceae, Artemisia, Brassicaceae, and Caryophyllaceae. An open tundra- and steppe-like vegetation complex during the Sartan stadial under general cold and dry conditions is assumed. However, shallow water bodies (e.g., ice-wedge polygon centres) were present as indicated by green algae colonies (Botryococcus, Pediastrum). Plant macrofossil records prove the occurrence of Arctic pioneer vegetation and tundra-steppe communities. Stable accumulation conditions in a polygon tundra landscape are assumed during Sartan times at Cape Mamontov Klyk due to the presence of large syngenetic ice wedges and uniform sedimentological and cryolithological parameters (Schirrmeister et al., 2008b).

\subsubsection{Taymyr Peninsula}

The lacustrine Ice Complex of lake basins was studied on Taymyr Peninsula at the easternmost extension of the late Pleistocene Eurasian Ice Sheet at the shores of Lake Labaz (site 8 in Fig. 1; Siegert et al., 1999; Andreev et al., 2002b) and Lake Taymyr (Cape Sabler, site 6 in Fig. 1; Derevyagin et al., 1999; Kienast et al., 2001; Andreev et al., 2003). Additional Sartan pollen data are available from Lake Levinson-Lessing sediments (site 7 in Fig. 1; Andreev et al., 2003).

Sartan sections at Lake Labaz consist of layered silts and silty sands with numerous plant remains that accumulated in dry lake basins between about 20 and 12 ka BP (Siegert et al., 1999). Ice wedge ice from these sections was obtained in drill cores, and averages at $-28 \%$ for $\delta^{18} \mathrm{O}$ and $-217 \%$ for $\delta \mathrm{D}$ (Fig. $6 \mathrm{c}$ ). The lacustrine Ice Complex exposed at Cape Sabler (Lake Taymyr) (profile SAO-1 in Derevyagin et al., 1999) formed in a shallow-water basin that periodically silted up and preserved syngenetically-frozen lacustrine, lacustrine-alluvial and lacustrine-peatland deposits. The material consists of weakly pronounced intersecting horizons of grey and yellowish-grey sandy silts with considerable inclusions of plant remains and peaty sections at different depths. Three sections with syngenetic ice-wedge generations are distinguished (Derevyagin et al., 1999). The middle section was dated to 18 to $12 \mathrm{ka}$ BP. The corresponding ice wedges were $2-2.5 \mathrm{~m}$ and $5-6 \mathrm{~m}$ wide in their upper parts The stable water isotope composition of one Late Sartan ice wedge (SAO-1, IW-3 in Derevyagin et al., 1999) revealed mean values of $-26 \%$ for $\delta^{18} \mathrm{O}$ and $-197 \%$ for $\delta \mathrm{D}$ (Fig. 6c). As on Bykovsky Peninsula (see chapter 5.2.2), the stable water isotope composition of ice wedges from Sartan stadial sections on Taymyr Peninsula fails to provide evidence for an extremely cold Sartan period (i.e. LGM) (Siegert et al., 1999).

The Sartan pollen records from permafrost deposits at Lake Labaz reflect an open steppe-like vegetation with Artemisia, Poaceae, Asteraceae, and herb tundra-like vegetation with dwarf Betula and Salix (Andreev et al., 2002b). Pollen-based climate reconstructions point to the coldest and driest conditions occurring between about 20 and $17 \mathrm{ka}$ BP with decreased temperatures ( $\mathrm{T}_{\text {January }} 5$ to $5.5^{\circ} \mathrm{C}, \mathrm{T}_{\text {July }} 3$ to $4{ }^{\circ} \mathrm{C}$, and $\mathrm{T}_{\text {Annual }} 4$ to $4.5^{\circ} \mathrm{C}$ cooler than today) and less annual precipitation ( $\mathrm{P}_{\text {Annual }} 50$ to $100 \mathrm{~mm}$ less than today). Rather low pollen concentrations point to discontinuous plant cover and/or low pollen production due to the harsh climate conditions during the Sartan stadial.

Pollen-based quantitative reconstructions are available from Cape Sabler Peninsula permafrost deposits and Lake LevinsonLessing sediments. The data indicate a cold ( $\mathrm{T}_{\text {January }} 2.5$ to $3.5^{\circ} \mathrm{C}$, $\mathrm{T}_{\text {July }} 1$ to $3{ }^{\circ} \mathrm{C}$, and $\mathrm{T}_{\text {Annual }} 1.5$ to $4.5^{\circ} \mathrm{C}$ cooler than today) and dry (PAnnual up to $100 \mathrm{~mm}$ less than today) climate for the Sartan stadial between 20 and $18 \mathrm{ka} \mathrm{BP}$ (Andreev et al., 2003). Such reconstruction is supported by plant macrofossil data from the Cape Sabler site dated to about $18 \mathrm{ka} \mathrm{BP}$ (Kienast et al., 2001). A predominance of xerophytes, a high proportion of cryophytes, and the complete absence of boreal species and hydrophytes together suggest a tundra-steppe vegetation that occurred under high aridity with extremely low temperatures and little winter snow cover.

\subsection{Implications for the LGM in the East Siberian Arctic}

The overall image of the Sartan period in the permafrost exposures studied around the Laptev Sea as drawn from vegetation data reflects cold and dry conditions after about 26 ka BP lasting until about 15 ka BP. Most extreme climate conditions might have occurred between about 24 and $18 \mathrm{ka}$ BP. Quantitative reconstructions estimate decreased summer temperatures and annual precipitation (Andreev et al., 2002b; Pitul'ko et al., 2007). Single records, i.e. plant macrofossil data with persisting thermophilic taxa on Bykovsky Peninsula (Kienast et al., 2005), contradict the general assumptions, but may reflect the occurrence of sheltered habitats on a local scale. The stable water isotope composition in ice wedges, interpreted as an indicator of winter temperatures, differentiates the western from the eastern part of the Laptev Sea region (Meyer, 2003). The westernmost ice wedges of the considered region on Taymyr Peninsula show the heaviest (warmest) stable-isotope composition that depletes eastward to lightest (coldest) values on Bol'shoy Lyakhovsky Island. (Table 4; Fig. 6c). This observation might be explained by the continentality effect (Dansgaard, 1964) at the later stages of the Rayleigh fraction process, if the same moisture source is assumed for all study sites. However, during the LGM large parts of the North Atlantic and the Barents and Kara seas were permanently ice-covered and the easternmost extents of the Eurasian Ice Sheet reached the western part of the Taymyr Peninsula (Svendsen et al., 2004). Therefore, the influence of Atlantic air masses in the study region was reduced because they were blocked or deflected by the ice sheet. In consequence, the moisture reaching the western Laptev Sea region during LGM might have originated from lower latitudes in the Atlantic due to maximum extension of the Eurasian Ice Sheet (Meyer et al., 2002a) or a stronger influence of the North Pacific winter moisture source might have existed (Meyer, 2003). Both moisture sources are likely characterised by relatively low d-excess values as reflected in Sartan ice wedges on Mamontov Klyk, Bykovsky Peninsula and Bol'shoy Lyakhovsky Island. Sartan ice wedges on Taymyr Peninsula do not resemble this observation. This might be explained by their younger ages ( $<20$ ka BP; Table 4 ) when a distinct northern Atlantic source for winter moisture replaced former LGM conditions in the Taymyr region (Meyer et al., 2002b).

The stable water isotope composition of the studied Sartan ice wedges reflects most depleted (coldest) $\delta^{18} \mathrm{O}$ and $\delta \mathrm{D}$ values, thus extremely cold winter conditions in the easternmost study site on Bol'shoy Lyakhovsky Island. The d-excess data could indicate a constant potentially Pacific moisture source for Bol'shoy Lyakhovsky Island (Meyer et al., 2002a; Meyer, 2003) differing from the study sites further west. Since Pacific moisture would have to pass orographic barriers prior to precipitation at Bol'shoy Lyakhovsky Island, it might be further distilled from the cloud (more developed Rayleigh-like process) than the samples from the western province. This could be a potential reason why the Sartan minimum has only been detected in ice wedges at this site.

\section{Conclusions}

The overall landscape and environmental setting for the Sartan period including the LGM in the East Siberian Arctic can be described as follows. 
(1) During the Sartan stadial hydrological pathways were altered due to sea level low stand and intensified fluvial erosion. Ongoing Ice Complex formation took place above Kargin interstadial Ice Complex in flat plains (e.g. Western and Central Laptev Sea region) or in valley positions (e.g. Eastern Laptev Sea region).

(2) Impoverished tundra-steppe vegetation (cold tundra-steppe or cryophyte steppe) is assumed for the Sartan stadial due to relatively low pollen concentrations with a characteristic predominance of grass pollen over sedge pollen. In particular, pollen assemblages of the Sartan stadial in the East Siberian Arctic typically contain pollen of Poaceae, Cyperaceae, Artemisia, Caryophyllaceae, Asteraceae, Brassicaceae, reworked conifers, and S. rupestris.

(3) Bol'shoy Lyakhovsky Island ice wedges indicate extremely cold winter temperatures during the Sartan stadial $\left(\delta^{18} \mathrm{O}_{\text {mean }}\right.$ of about $-37 \%$ o $\delta \mathrm{D}_{\text {mean }}$ of about $-290 \%$ ); this is in contrast to results from Sartan ice wedges studied farther west in the Laptev Sea area $\left(\delta^{18} \mathrm{O}_{\text {mean }}\right.$ between $-31 \%$ and $-26 \%$, $\delta \mathrm{D}_{\text {mean }}$ between $-245 \%$ and $-197 \%$ ). The spatial appearance of LGM conditions reflected in ice-wedge stable isotope data differs between records from Bol'shoy Lyakhovsky and those from areas farther west due to different winter moisture sources.

(4) The temporal appearance of LGM conditions in East Siberian permafrost as represented by pollen and ground ice data differs somewhat within the region, but delineates a general trend to coldest and driest climate conditions between about 24 and 18 ka BP.

\section{Acknowledgements}

The study presented here is part of the Russian-German "System Laptev Sea"cooperative scientific effort, and the International Polar Year "Past Permafrost" project (IPY project 15). The paper presented here contributes to the joint German-Russian DFG-RFBR research project 'Polygons in tundra wetlands: State and dynamics under climate variability in polar regions (POLYGON)'. We thank our colleagues who helped during fieldwork in 2007, especially Dmitry Dobrynin (Moscow State University) and Fedor Selyakhov (Lena Delta Reserve Tiksi) who provided accomodation in his fieldcamp at the Zimov'e River mouth and logistical support. The analytical work in the AWI laboratories was expertly conducted by Ute Bastian and Lutz Schönicke. Birgit Plessen capably performed the analyses of $\delta^{13} \mathrm{C}$ of TOC at Deutsches GeoForschungsZentrum Potsdam, Germany. Tatyana Kuznetsova from Moscow State University identified the dated bone material. The palynological work of Natalia Rudaya was supported by the German Academic Exchange Service via a personal grant (DAAD grant $\mathcal{N} \circ$ A1008070). The paper benefited by valuable comments and English language correction from Candace O'Connor (University of Alaska, Fairbanks). We finally thank two anonymous reviewers for very constructive suggestions that improved the paper.

\section{References}

Andreev, A.A., Schirrmeister, L., Siegert, C., Bobrov, A.A., Demske, D., Seiffert, M., Hubberten, H.-W., 2002a. Paleoenvironmental changes in north-eastern Siberia during the Late Pleistocene - evidence from pollen records of the Bykovsky Peninsula. Polarforschung 70, 13-25.

Andreev, A.A., Siegert, C., Klimanov, V.A., Derevyagin, A.Yu., Shilova, G.N., Melles, M., 2002b. Late Pleistocene and Holocene vegetation and climate on the Taymyr lowland, northern Siberia. Quaternary Research 57, 138-150.

Andreev, A.A., Tarasov, P.E., Siegert, C., Ebel, T., Klimanov, V.A., Melles, M., Bobrov, A.A., Dereviagin, A.Yu., Lubinski, D.J., Hubberten, H.-W., 2003. Vegetation and climate changes on the northern Taymyr, Russia during the upper Pleistocene and Holocene reconstructed from pollen records. Boreas 32, 484-505.

Andreev, A.A., Grosse, G., Schirrmeister, L., Kuzmina, S.A., Novenko, E.Yu., Bobrov, A.A., Tarasov, P.E., Kuznetsova, T.V., Krbetschek, M., Meyer, H., Kunitsky, V.V., 2004. Late
Saalian and Eemian palaeoenvironmental history of the Bol'shoy Lyakhovsky island (Laptev Sea region, arctic Siberia). Boreas 33, 319-348.

Andreev, A.A., Grosse, G., Schirrmeister, L., Kuznetsova, T.V., Kuzmina, S.A., Bobrov, A.A., Tarasov, P.E., Novenko, E.Yu., Meyer, H., Derevyagin, A.Yu., Kienast, F., Bryantseva, A., Kunitsky, V.V., 2009. Weichselian and Holocene palaeoenvironmental history of the Bol'shoy Lyakhovsky island, New Siberian Archipelago, arctic Siberia. Boreas 38, 72-110.

Andreev, A., Schirrmeister, L., Tarasov, P.E., Ganopolski, A., Brovkin, V., Siegert, C., Wetterich, S., Hubberten, H.-W.. Vegetation and climate history in the Laptev Sea region (Arctic Siberia) during late Quaternary inferred from pollen records. Quaternary Science Reviews, doi:10.1016/j.quascirev.2010.12.026, in press.

Arkhangelov, A.A., Mikhalev, D.V., Nikolaev, V.I., 1996. Reconstruction of formation conditions of permafrost and palaeoclimate of Northern Eurasia. In: Velichko, A.A., Arkhangelov, A.A., Borisova, O.K., Gribchenko, Y.N., Drenova, A.N., Zelikson, E.M., Kurenkova, E.N., Mikhalev, D.V., Nikolaev, V.I., Novenko, E.Y., Timireva, S.A. (Eds.), Razvitie oblasti mnnogoletnei merzloty i periglyatsial'noi zony Severnoi Evrazii i usloviya rasseleniya drevnego cheloveka. RAS Institute of Geography, Moscow, pp. 85-109 (in Russian).

Berman, D., Alfimov, A., Kuzmina, S. Invertebrates of the relict steppe ecosystems of Beringia, and the reconstruction of Pleistocene landscapes. Quaternary Science Reviews, doi:10.1016/j.quascirev.2010.09.016, in press.

Bobrov, A.A., Andreev, A.A., Schirrmeister, L., Siegert, C., 2004. Testate amoebae (Protozoa: Testacea) as bioindicators in the late Quaternary deposits of the Bykovsky Peninsula, Laptev Sea, Russia. Palaeogeography Palaeoclimatology Palaeoecology 209, 165-181.

Bunge, A.A., 1887. Bericht über den ferneren Gang der Expedition. Reise nach den Neusibirischen Inseln. Aufenthalt auf der Grossen Ljachof-Insel. In: Schrenk, L.V., Maximovicz, C.J. (Eds.), Expedition zu den Neusibirischen Inseln und dem Jana-Lande (1885). Beiträge zur Kenntnis des russischen Reiches und der angrenzenden Länder, vol. III. Kaiserliche Akademie der Wissenschaften, St. Petersburg, pp. 231-284.

Clark, P.U., Dyke, A.S., Shakun, J.D., Carlson, A.E., Clark, J., Wohlfarth, B., Mitrovica, J.X., Hostetler, S.W., McCabe, A.M., 2009. The last glacial maximum. Science 325, 710-714.

Craig, H., 1961. Isotopic variations in meteoric waters. Science 133, 1702-1703.

Dansgaard, W., 1964. Stable isotopes precipitation. Tellus 16, 436-468.

Derevyagin, A.Yu., Chizhov, A.B., Brezgunov, V.S., Siegert, C., Hubberten, H.-W., 1999. Isotopic composition of ice wedges of Cape Sabler (Lake Taymyr). Earth Cryosphere 3/3, 41-49 (in Russian).

Dostovalov, B.N., Kudryavtsev, V.A., 1967. Obshchaya Geokriologiya (Common Geocryology). Moscow State University Press, Moscow. 403 p. (in Russian)

Drachev, S.S., Savostin, L.A., Groshev, V.G., Bruni, I.E., 1998. Structure and geology of the continental shelf on the Laptev Sea, eastern Russian arctic. Tectonophysics 298, 357-393.

Edwards, M.E., Anderson, P.M., Brubaker, L.B., Ager, T.A., Andreev, A.A., Bigelow, N.H., Cwynar, L.C., Eisner, W.R., Harrison, S.P., Hu, F.S., Jolly, D., Lozhkin, A.V., MacDonald, G.M., Mock, C.J., Ritchie, J.C., Sher, A.V., Spear, R.W., Williams, J.W., Yu, G., 2000. Pollen-based biomes for Beringia 18,000, 6000 and 0 C-14 yr BP. Journal of Biogeography 27, 521-554.

Fægri, K., Iversen, J., 1989. Textbook of Pollen Analysis, fourth ed. John Wiley \& Sons, Chichester, $328 \mathrm{pp}$.

French, H.M., Shur, Y., 2010. The principles of cryostratigraphy. Earth Science Reviews 101, 190-206.

Froese, D.G., Westgate, J.A., Reyes, A.V., Enkin, R.J., Preece, S.J., 2008. Ancient permafrost and a future, warmer Arctic. Science 321, 1648.

Grimm, E., 1991. TILIAGRAPH vl.25. Illinois State Museum, Research and Collections Center, Springfield, Illinois, USA.

Grimm, E., 1993. TILIA v2.0. Illinois State Museum, Research and Collections Center, Springfield, Illinois, USA

Grootes, P.M., Nadeau, M.J., Rieck, A., 2004. ${ }^{14}$ C-AMS at the Leibniz-Labor: radiometric dating and isotope research. Nuclear Instruments and Methods in Physics Research 223, 55-61.

Grosse, G., Schirrmeister, L., Siegert, C., Kunitsky, V., Slagoda, E.A., Andreev, A.A., Dereviagin, A.Y.u, 2007. Geological and geomorphological evolution of a sedimentary periglacial landscape in Northeast Siberia during the Late Quaternary. Geomorphology 86, 25-51.

Hubberten, H.-W., Andreev, A., Astakhov, V.I., Demidov, I., Dowdeswell, J.A., Henriksen, M., Hjort, C., Houmark-Nielsen, M., Jakobsson, M., Kuzmina, S., Larsen, E., Lunkka, J.P., Lysa, A., Mangerud, J., Möller, P., Saarnisto, M., Schirrmeister, L., Sher, A.V., Siegert, C., Siegert, M.J., Svendsen, J.I., 2004. The periglacial climate and environment in northern Eurasia during the last glaciation. Quaternary Science Reviews 23, 1333-1357.

Ilyashuk, B.P., Andreev, A.A., Bobrov, A.A., Tumskoy, V.E., Ilyashuk, E.A., 2006. Interglacial history of a palaeo-lake and regional environment: a multi-proxy study of a permafrost deposit from Bol'shoi Lyakhovsky Island, Arctic Siberia. Journal of Paleolimnology 36, 855-872.

Kanevskiy, M., Shur, Y., Fortier, D., Jorgenson, M.T., Stephani, E. Cryostratigraphy of late Pleistocene syngenetic permafrost (yedoma) in northern Alaska, Itkillik River exposure. Quaternary Research, doi:10.1016/j.yqres.2010.12.003, in press.

Kaplina, T.N., 2011. Ancient alas complexes of Northern Yakutia, first note (Drevnie alasnye kompleksy Severnoi Yakutii, soobshchenie 1). Earth Cryosphere 15 (2), 3-13 (in Russian).

Kienast, F., Siegert, C., Dereviagin, A., Mai, D.H., 2001. Climatic implications of late Quaternary plant macrofossil assemblages from the Taymyr Peninsula, Siberia. Global and Planetary Change 31, 265-281. 
Kienast, F., Schirrmeister, L., Siegert, C., Tarasov, P., 2005. Palaeobotanical evidence for warm summers in the East Siberian Arctic during the last cold stage. Quaternary Research 63, 283-300.

Kienast, F., Tarasov, P., Schirrmeister, L., Grosse, G., Andreev, A.A., 2008. Continental climate in the East Siberian Arctic during the last interglacial: implications from palaeobotanical records. Global and Planetary Change 60, 535-562.

Kienast, F., Wetterich, S., Kuzmina, S., Schirrmeister, L., Andreev, A., Tarasov, P., Nazarova, L., Kossler, A., Frolova, L., Kunitsky, V.V. Paleontological records indicate the occurrence of open woodlands in a dry inland climate at the present-day Arctic coast in western Beringia during the last interglacial. Quaternary Science Reviews, doi:10.1016/j.quascirev.2010.11.024, in press.

Kunitsky, V.V., 1998. Ice complex and cryoplanation terraces of the Bol'shoy Lyakhovsky island. In: Kamensky, R.M., Kunitsky, V.V., Olovin, B.A., Shepelev, V.V. (Eds.), Problemy Geokriologii. RAS SB Permafrost Institute, Yakutsk, Russia, pp. 60-72 (in Russian).

Kuznetsova, L.P., 1998. Atmospheric moisture content and transfer over the territory of the former USSR. In: Ohata, T., Hiyama, T. (Eds.), Second International Workshop on Energy and Water Cycle in GAMESiberia, 1997, pp. 145-151. Research Report of the Institute for Hydrospheric-Atmospheric Sciences, University of Nagoya Japan.

Lachenbruch, A.H., 1962. Mechanics of thermal contraction cracks and ice-wedge polygons in permafrost, GSA, US Geological Survey, New York, $67 \mathrm{pp}$

Lozhkin, A.V., 2002. Modern pollen rain in the arctic regions of Beringia and the reconstruction of vegetation during the glacial intervals of the Pleistocene. In: Simakov, K.V. (Ed.), Chetvertichnaya paleogeografiya Beringii. RAS FEB NEISRI, Magadan, Russia, pp. 13-27 (in Russian).

Mackay, J.R., 1983. Oxygen isotope variations in permafrost, Tuktoyaktuk Peninsula area, Northwest Territories. Geological Survey of Canada, 67-74. Current Research Part B Paper 83-1B.

Medeanic, S., 2006. Freshwater algal palynomorph records from the Holocene deposits in the coastal Plain of Rio Grande do Sul, Brazil. Review of Palaeobotany and Palynology 141, 83-101.

Meyer, H., 2003. Late Quaternary climate history of Northern Siberia - evidence from ground ice. Berichte zur Polar- und Meeresforschung 461, 1-109.

Meyer, H., Schönicke, L., Wand, U., Hubberten, H.-W., Friedrichsen, H., 2000. Isotope studies of hydrogen and oxygen in ground ice - experiences with the equilibration technique. Isotopes in Environmental and Health Studies 36, 133-149.

Meyer, H., Dereviagin, A., Siegert, C., Schirrmeister, L., Hubberten, H.-W., 2002a. Palaeoclimate reconstruction on Big Lyakhovsky Island, North Siberia hydrogen and oxygen isotopes in ice wedges. Permafrost and Periglacial Processes 13, 91-105.

Meyer, H., Dereviagin, A.Yu., Siegert, C., Hubberten, H.-W., 2002b. Paleoclimate studies on Bykovsky Peninsula, North Siberia - hydrogen and oxygen isotopes in ground ice. Polarforschung 70, 37-51.

Meyer, H., Schirrmeister, L., Yoshikawa, K., Opel, T., Wetterich, S., Hubberten, H.-W., Brown, J., 2010. Permafrost evidence for severe winter cooling during the Younger Dryas in northern Alaska. Geophysical Research Letters 37, L03501.

Miller, G.H., Brigham-Grette, J., Alley, R.B., Anderson, L., Bauch, H.A., Douglas, M., Edwards, M.E., Elias, S.A., Finney, B., Fitzpatrick, J.J., Funder, S.V., Herbert, T.D. Hinzman, L., Kaufman, D., MacDonald, G.M., Polyak, L., Robock, A., Serreze, M., Smol, J., Spielhagen, R., White, J.W.C., Wolfe, A.P., 2010. Temperature and precipitation history of the Arctic. Quaternary Science Reviews 29, 1679-1715.

Nagaoka, D., Saijo, K., Fukuda, M., 1995. Sedimental environment of the Yedoma in high Arctic eastern Siberia. In: Proceedings of the 3rd symposium on the joint Siberian permafrost studies between Japan and Russia in 1994. Hokkaido University Press, Sapporo, Japan, pp. 8-13.

Pitul'ko, V.V., Pavlova, E.Yu, 2010. Geoarkheologiya i radiouglerodnaya khronologiya kamennogo veka severo-vostochnoi Azii (Geoarcheology and radiocarbon chronology of the Stone Age in North-East Asia). Nauka, St. Petersburg, Russia. 263 p. (in Russian).

Pitul'ko, V.V., Pavlova, E.Yu., Kuz'mina, S.A., Nikol'skii, P.A., Basilyan, A.E., Tumskoi, V.E., Anisimov, M.A., 2007. Natural-climatic changes in the YanaIndigirka lowland during the terminal Kargino time and habitat of late Paleolithic man in northern part of East Siberia. Doklady Earth Sciences 417, 103-108.

Reille, M., 1992. Pollen et spores d'Europe et d'Afrique du nord. Laboratoire de botanique historique et palynologie, URA CNRS, Marseille, France.

Reille, M., 1995. Pollen et spores d'Europe et d'Afrique du nord, Supplement 1. Laboratoire de botanique historique et palynologie, URA CNRS, Marseille, France.

Reille, M., 1998. Pollen et spores d'Europe et d'Afrique du nord, Supplement 2. Laboratoire de botanique historique et palynologie, URA CNRS, Marseille, France.

Romanovskii, N.N., 1958. New data about the structure of Quaternary deposits on the Bol'shoy Lyakhovsky island, New Siberian islands. Nauchnye Doklady Vysshei Shkoly. Seriya geologo-geograficheskaya 2, 243-248 (in Russian).

Schirrmeister, L., Oezen, D., Geyh, M.A., 2002a. ${ }^{230} \mathrm{Th} / \mathrm{U}$ dating of frozen peat, Bol'shoyLyakhovsky Island (North Siberia). Quaternary Research 57, 253-258.

Schirrmeister, L., Siegert, C., Kuznetsova, T., Kuzmina, S., Andreev, A.A., Kienast, F., Meyer, H., Bobrov, A., 2002b. Paleoenvironmental and paleoclimatic records from permafrost deposits in the Arctic region of Northern Siberia. Quaternary International 89, 97-118.
Schirrmeister, L., Grosse, G., Schwamborn, G., Andreev, A.A., Meyer, H. Kunitsky, V.V., Kuznetsova, T.V., Dorozhkina, M.V., Pavlova, E.Y., Bobrov, A.A. Oezen, D., 2003. Late Quaternary history of the accumulation plain north of the Chekanovsky Ridge (Lena Delta, Russia): a multidisciplinary approach. Polar Geography 27, 277-319.

Schirrmeister, L., Wetterich, S., Tumskoy, V., Dobrynin, D., 2008a. Palaeoenvironmental studies on Bol'shoy Lyakhovsky island. Berichte zur Polar- und Meeresforschung 584, 51-84.

Schirrmeister, L., Grosse, G., Kunitsky, V., Magens, D., Meyer, H., Dereviagin, A. Kuznetsova, T., Andreev, A., Babiy, O., Kienast, F., Grigoriev, M., Overduin, P.P. Preusser, F., 2008b. Periglacial landscape evolution and environmental changes of Arctic lowland areas for the last 60,000 years (western Laptev Sea coast, Cape Mamontov Klyk). Polar Research 27, 249-272.

Schirrmeister, L., Kunitsky, V., Grosse, G., Wetterich, S., Meyer, H., Schwamborn, G. Babiy, O., Derevyagin, A., Siegert, C. Sedimentary characteristics and origin of the Late Pleistocene Ice Complex on North-East Siberian Arctic coastal lowlands and islands - a review. Quaternary International, doi:10.1016/j.quaint.2010.04. 004 , in press.

Schwamborn, G., Meyer, H., Fedorov, G., Schirrmeister, L., Hubberten, H.-W., 2006. Ground ice and slope sediments archiving late Quaternary paleoenvironment and paleoclimate signals at the margins of El'gygytgyn Impact Crater, NE Siberia. Quaternary Research 66, 259-272.

Schwamborn, G., Fedorov, G., Schirrmeister, L., Meyer, H., Hubberten, H.-W., 2008. Periglacial sediment variations controlled by Late Quaternary climate and lake level rise at Elgygytgyn Crater, Arctic Siberia. Boreas 37, 55-65.

Sher, A.V., 1997. Yedoma as a store of paleoenvironmental records in Beringia. In: Abstracts and Program of the Beringian Paleoenvironments Workshop. September 20-23, 1997, Florissant, Colorado, USA, pp. 92-94.

Sher, A.V., Kaplina, T.N., Ovander, M.G., 1987. Unified regional stratigraphic chart for the Quaternary deposits in the Yana-Kolyma lowland and its mountainous surroundings. Explanatory Note. In: Resheniya mezhvedomstvenogo stratigraficheskogo soveshchaniya po chetvertichnoi sisteme vostoka SSSR, Magadan, 1982. USSR Academy of Sciences FEB NEISRI, Magadan, Russia, pp. 29-69 (In Russian).

Sher, A.V., Kuzmina, S.A., Kuznetsova, T.V., Sulerzhitsky, L.D., 2005. New insights into the Weichselian environment and climate of the Eastern-Siberian Arctic derived from fossil insects, plants, and mammals. Quaternary Science Reviews 24, 533-569.

Siegert, C., Derevyagin, A.Yu., Shilova, G.M., Hermichen, W.-D., Hiller, A., 1999. Paleoclimate indicators from permafrost sequences in the eastern Taymyr lowland. In: Kassens, H., Bauch, H.A., Dmitrenko, I.A., Eicken, H., Hubberten, H.-W. Melles, M., Thiede, J., Timokhov, L.A. (Eds.), Land-Ocean System in the Siberian Arctic: Dynamics and History. Springer, Berlin, Heidelberg, Germany, pp. 477-499.

Siegert, C., Schirrmeister, L., Babiy, O., 2002. The sedimentological, mineralogical and geochemical composition of late Pleistocene deposits from the ice complex on the Bykovsky Peninsula, northern Siberia. Polarforschung 70, 3-11.

Solov'ev, P.A., 1959. Kriolitozona severnoi chasti Leno-Amginskogo mezhdurech'ya (The cryolithozone in the northern part of the Lena-Amga-Interfluve) Publications of the USSR Academy of Science, Moscow, Russia, 144 p. (in Russian).

Stauch, G., Gualtieri, L., 2008. Late Quaternary glaciations innortheastern Russia. Journal of Quaternary Science 23, 545-558.

Svendsen, J.I., Alexanderson, H., Astakhov, V.I., Demidov, I., Dowdeswell, J.A. Funder, S., Gataullin, V., Henriksen, M., Hjort, C., Houmark-Nielsen, M. Hubberten, H.-W., Ingólfsson, Ó, Jakobsson, M., Kjær, K.H., Larsen, E., Lokrantz, H., Lunkka, J.P., Lyså, A., Mangerud, J., Matiouchkov, A., Murray, A., Möller, P., Niessen, F., Nikolskaya, O., Polyakh, L., Saarnisto, M., Siegert, C., Siegert, M.J., Spielhagen, R.F., Stein, R., 2004. Late Quaternary ice sheet history of northern Eurasia. Quaternary Science Reviews 23, 1229-1271.

Tumskoy, V.E., 2004. Geologicheskoe stroenie i vozrast otlozhenii ledovogo kompleksa v paione obnazheniya Mys-Khaya, p. Yana (Geological structure and age of Ice Complex deposits at the Mys-Khaya exposure, Yana River). In: Abstracts of the International Conference "Cryosphere of oil and gas bearing provinces", Tyumen, Russia, pp. 81. (in Russian).

Tumskoy, V.E., Basilyan, A.E., 2009. Quaternary stratigraphy of the Dmitry Laptev Strait coasts (Northern Yakutia). In: Kontorovich, A.E., Volkova, V.S., Khazina, I.V., Khazin, L.B. (Eds.), Fundamental problems of Quaternary: Results and Trends of Future Researches - Proceedings of the 6th All-Russian Quaternary Conference. RAS SB Publishers, Novosibirsk, Russia, pp. 592-593 (in Russian).

Vaikmäe, R., 1989. Oxygen isotopes in permafrost and in ground ice - a new tool for paleoclimatic investigations. Proceedings of the 5th working meeting "Isotopes in Nature", September 25-29, 1989. Leipzig, Germany, pp. 543-551.

van Everdingen, R.O. (Ed.), 1998. Multi-language glossary of permafrost and related groundice terms. Arctic Institute of North America, University of Calgary, Canada, p. 268

van Geel, B., van der Hammen, T., 1978. Zygnemataceae in Quaternary Colombian sediments. Review of Palaeobotany and Palynology 25, 377-392.

Vasil'chuk, Y.K., Vasil'chuk, A.C., 1995. Ice-wedge formation in northern Asia during the Holocene. Permafrost and Periglacial Processes 6, 273-279.

Velichko, A.A., Curry, B., Ehlers, J., 2005. Main Quaternary chronostratigraphical units used in Siberia, east-European plain, west Europe and North America. In: Velichko, A.A., Nechaev, V.P. (Eds.), Cenozoic climatic and environmenta changes in Russia. The Geological Society of America, p. XVII. Special Paper 382. 
von Toll, E.V., 1897. Fossil glaciers of New Siberian Islands, their relation to mammoth corpses and the Glacial period. Zapiski Imperatorskogo Russkogo Geograficheskogo Obshestva po Obshei Geografii 32, 1-137 (in Russian).

Wetterich, S., Schirrmeister, L., Pietrzeniuk, E., 2005. Freshwater ostracodes in Quaternary permafrost deposits from the Siberian Arctic. Journal of Paleolimnology 34, 363-374.

Wetterich, S., Kuzmina, S., Andreev, A.A., Kienast, F., Meyer, H., Schirrmeister, L. Kuznetsova, T., Sierralta, M., 2008. Palaeoenvironmental dynamics inferred from late Quaternary permafrost deposits on Kurungnakh island, Lena delta, Northeast Siberia, Russia. Quaternary Science Reviews 27, 1523-1540.
Wetterich, S., Schirrmeister, L., Andreev, A.A., Pudenz, M., Plessen, B., Meyer, H., Kunitsky, V.V. 2009. Eemian and Late Glacial/Holocene palaeoenvironmental records from permafrost sequences at the Dmitry Laptev Strait (NE Siberia, Russia). Paleogeography, Paleoclimatology, Paleoecology 279, 73-95.

Yershov, E.D., Kondratyeva, K.A., Zamolotchikova, S.A., Trush, N.I., Dunaeva, Ye.N 1985. Geocryological Map of the USSR. Faculty of Geology. Moscow State University, Moscow, Russia. Scale 1:2,500,000 (in Russian).

Yurtsev, B.A., 2001. The Pleistocene "Tundra-Steppe" and the productivity paradox: the landscape approach. Quaternary Science Reviews 20, 165-174. 